\title{
Intercomparison and evaluation of satellite peroxyacetyl nitrate observations in the upper troposphere-lower stratosphere
}

\author{
Richard J. Pope ${ }^{1,2}$, Nigel A. D. Richards ${ }^{1,2}$, Martyn P. Chipperfield ${ }^{1,2}$, David P. Moore ${ }^{3,4}$, Sarah A. Monks ${ }^{5,7}$, \\ Stephen R. Arnold ${ }^{1}$, Norbert Glatthor ${ }^{6}$, Michael Kiefer ${ }^{6}$, Tom J. Breider ${ }^{8}$, Jeremy J. Harrison ${ }^{3,4}$, John J. Remedios ${ }^{3,4}$, \\ Carsten Warneke $^{5,7}$, James M. Roberts ${ }^{5}$, Glenn S. Diskin ${ }^{9}$, Lewis G. Huey ${ }^{10}$, Armin Wisthaler ${ }^{11,12}$, Eric C. Apel ${ }^{13}$, \\ Peter F. Bernath ${ }^{14}$, and Wuhu Feng ${ }^{1,15}$ \\ ${ }^{1}$ School of Earth and Environment, University of Leeds, Leeds, UK \\ ${ }^{2}$ National Centre for Earth Observation, University of Leeds, Leeds, UK \\ ${ }^{3}$ Department of Physics and Astronomy, University of Leicester, Leicester, UK \\ ${ }^{4}$ National Centre for Earth Observation, University of Leicester, Leicester, UK \\ ${ }^{5}$ Earth System Research Laboratory, National Oceanic and Atmospheric Administration, Boulder, CO, USA \\ ${ }^{6}$ Karlsruhe Institute of Technology, Institute of Meteorology and Climate Research, Karlsruhe, Germany \\ ${ }^{7}$ Cooperative Institute for Research in Environmental Sciences, University of Colorado, Boulder, CO, USA \\ ${ }^{8}$ School of Engineering and Applied Sciences, Harvard University, Cambridge, USA \\ ${ }^{9}$ NASA Langley Research Center, Chemistry and Dynamics Branch, Hampton, VA, USA \\ ${ }^{10}$ Georgia Institute of Technology, Atlanta, GA, USA \\ ${ }^{11}$ University of Innsbruck, Innsbruck, Austria \\ ${ }^{12}$ University of Oslo, Oslo, Norway \\ ${ }^{13}$ Atmospheric Chemistry Division, National Centre for Atmospheric Research, Boulder, CO, USA \\ ${ }^{14}$ Department of Chemistry and Biochemistry, Old Dominion University, Norfolk, VA, USA \\ ${ }^{15}$ National Centre for Atmospheric Science, University of Leeds, Leeds, UK
}

Correspondence to: Richard J. Pope (r.j.pope@ leeds.ac.uk)

Received: 9 May 2016 - Published in Atmos. Chem. Phys. Discuss.: 13 June 2016

Revised: 17 August 2016 - Accepted: 22 September 2016 - Published: 1 November 2016

\begin{abstract}
Peroxyacetyl nitrate (PAN) is an important chemical species in the troposphere as it aids the long-range transport of $\mathrm{NO}_{x}$ and subsequent formation of $\mathrm{O}_{3}$ in relatively clean remote regions. Over the past few decades observations from aircraft campaigns and surface sites have been used to better understand the regional distribution of PAN. However, recent measurements made by satellites allow for a global assessment of PAN in the upper troposphere-lower stratosphere (UTLS). In this study, we investigate global PAN distributions from two independent retrieval methodologies, based on measurements from the Michelson Interferometer for Passive Atmospheric Sounding (MIPAS) instrument, on board Envisat from the Institute of Meteorology and Climate Research (IMK), Karlsruhe Institute of Technology, and the Department of Physics and Astronomy, University of Leicester (UoL). Retrieving PAN from MIPAS is
\end{abstract}

challenging due to the weak signal in the measurements and contamination from other species. Therefore, we compare the two MIPAS datasets with observations from the Atmospheric Chemistry Experiment Fourier transform spectrometer (ACE-FTS), in situ aircraft data and the 3-D chemical transport model TOMCAT. MIPAS shows peak UTLS PAN concentrations over the biomass burning regions (e.g. ranging from 150 to $>200 \mathrm{pptv}$ at $150 \mathrm{hPa}$ ) and during the summertime Asian monsoon as enhanced convection aids the vertical transport of PAN from the lower atmosphere. At $150 \mathrm{hPa}$, we find significant differences between the two MIPAS datasets in the tropics, where IMK PAN concentrations are larger by $50-100$ pptv. Comparisons between MIPAS and ACE-FTS show better agreement with the UoL MIPAS PAN concentrations at $200 \mathrm{hPa}$, but with mixed results above this altitude. TOMCAT generally captures the mag- 
nitude and structure of climatological aircraft PAN profiles within the observational variability allowing it to be used to investigate the MIPAS PAN differences. TOMCAT-MIPAS comparisons show that the model is both positively (UoL) and negatively (IMK) biased against the satellite products. These results indicate that satellite PAN observations are able to detect realistic spatial variations in PAN in the UTLS, but further work is needed to resolve differences in existing retrievals to allow quantitative use of the products.

\section{Introduction}

Peroxyacetyl nitrate $\left(\mathrm{PAN} ; \mathrm{CH}_{3} \mathrm{C}(\mathrm{O}) \mathrm{OONO}_{2}\right)$ is a key species in the chemistry of the troposphere. PAN is produced in polluted regions through the reaction of hydrocarbons which contain an acetyl group $\left(-\mathrm{C}(\mathrm{O}) \mathrm{CH}_{3}\right)$, such as acetone and acetaldehyde, with $\mathrm{OH}$ and $\mathrm{O}_{2}$ to form the peroxyacetyl radical $\left(\mathrm{CH}_{3} \mathrm{C}(\mathrm{O}) \mathrm{OO}\right)$. The subsequent reversible temperature-dependent reaction of the peroxyacetyl radical with nitrogen dioxide $\left(\mathrm{NO}_{2}\right)$ produces PAN:

$$
\mathrm{CH}_{3} \mathrm{C}(\mathrm{O}) \mathrm{OO}+\mathrm{NO}_{2}+M \rightleftharpoons \mathrm{PAN}+M,
$$

where $M$ is a third body. PAN produced at the surface can be uplifted into the cold upper troposphere (UT) where it has a relatively long lifetime of several months (Singh, 1987; Talukdar et al., 1995), enabling it to be transported over large distances. PAN therefore acts as a reservoir for $\mathrm{NO}_{x}(\mathrm{NO}+$ $\mathrm{NO}_{2}$ ) in the UT. When UT air masses descend and warm, PAN breaks down to release $\mathrm{NO}_{2}$, which may promote ozone production in regions with small local $\mathrm{NO}_{x}$ sources (Wang et al., 1998; Hudman et al., 2004). PAN therefore plays an important role in the long-range transport of pollution to remote clean areas and has a strong influence on the oxidizing capacity of the troposphere.

Initial observations of tropospheric PAN came from a small number of aircraft campaigns (Singh et al., 1996, 2000; Russo et al., 2003; Roberts et al., 2004; Lewis et al., 2007). These observations showed that PAN is widespread throughout the mid and upper troposphere, with remote background concentrations of between 50 and 100 pptv (Singh et al., 2000) increasing up to $1000 \mathrm{pptv}$ in some polluted air masses (Russo et al., 2003). The first global measurements of uppertropospheric PAN were retrieved from the Michelson Interferometer for Passive Atmospheric Sounding (MIPAS) instrument on board Envisat (Glatthor et al., 2007; Moore and Remedios, 2010; Wiegele et al., 2012). Glatthor et al. (2007) demonstrated the ability of MIPAS to retrieve PAN in the upper troposphere-lower stratosphere (UTLS) region with a height resolution of 3.5-6 km. They also demonstrated that MIPAS was able to observe PAN in Southern Hemisphere biomass burning plumes, with similar concentrations to previous aircraft campaigns. Furthermore, Moore and Remedios (2010) demonstrated that MIPAS is able to capture the sea- sonal cycle of PAN in the UTLS. In the BORTAS (quantifying the impact of BOReal forest fires on Tropospheric oxidants over the Atlantic using Aircraft and Satellites) campaign, Tereszchuk et al. (2013) showed that three PAN profiles from ACE-FTS (Atmospheric Chemistry Experiment Fourier Transform Spectrometer) agree with MIPAS data (from Moore and Remedios, 2010) within the respective error margins above $150 \mathrm{hPa}$ when observing the biomass burning outflow from North America in July 2011. More recently, Ungermann et al. (2016) used observations from the Cryogenic Infrared Spectrometers and Telescopes for the Atmosphere (CRISTA) infrared limb sounder, on board the NASA Space Shuttle in August 1997, to investigate the enhancement of PAN in the Asian summer monsoon anticyclone. At $380 \mathrm{~K}$, CRISTA retrieved peak PAN concentrations of over 350 pptv.

Previous modelling studies of PAN have concentrated on the effects of volatile organic compounds (VOCs) on PAN formation. Pfister et al. (2008) showed that isoprene can contribute up to $29 \%$ of the annual global atmospheric PAN burden. Ito et al. (2007) found a $40 \%$ increase in modelled PAN concentrations with the inclusion of aromatic and terpenoid hydrocarbons and hydroxyl alkyl nitrates produced from isoprene. Fischer et al. (2014) demonstrated that acetaldehyde (44\%) and methyglyoxal (37\%) are the primary VOCs leading to the formation of the peroxyacetyl radical. Isoprene $(37 \%)$ and alkanes $(14 \%)$ are the main emissions aiding PAN formation. Emmons et al. (2015) led a model inter-comparison project (including models such as the 3-D chemical transport model TOMCAT and the Goddard Earth Observing System tropospheric chemistry model (GEOSChem)) looking at tropospheric chemistry in the Arctic. They found that the majority of models reproduce the same seasonal cycle at $700 \mathrm{hPa}$ between 50 and $70^{\circ} \mathrm{N}$, with peak PAN in March-May. When compared with flight campaigns, the majority of the models (including TOMCAT) overestimated PAN concentrations in the lower troposphere. Arnold et al. (2015) investigated the influence of biomass burning on northern high-latitude tropospheric PAN and found that chemical transport models (CTMs) using ERA-Interim meteorology overestimated the PAN observations, while those that used GEOS-5 meteorology underestimated PAN. Fadnavis et al. (2014) used the ECHAM5-HAMMOZ global chemistry-climate model (CCM) and MIPAS PAN observations (from Karlsruhe Institute of Technology) between 2002 and 2011 to detect peak vertical transport of PAN into the UTLS during the Asian summertime monsoon. However, compared to MIPAS, ECHAM5-HAMMOZ had a low bias in the seasonal cycle (approximately 100 pptv) in JuneAugust.

In this paper we use a synthesis of satellite and aircraft data and the TOMCAT CTM to find robust features of PAN in the UTLS and quantify its uncertainty. In particular, we compare two different retrievals of PAN from the MIPAS satellite with ACE-FTS retrievals. Section 2 describes the ob- 
servations used and the TOMCAT model configuration. We discuss our model-observation inter-comparisons in Sect. 3 and present our conclusions in Sect. 4.

\section{Observations and model}

\subsection{Satellite and aircraft observations}

The primary observations used in this paper are retrieved from the MIPAS and ACE-FTS satellite instruments. We used data from two different MIPAS retrievals performed by the University of Leicester (UoL) and the Institute of Meteorology and Climate Research, Karlsruhe Institute of Technology (IMK). The UoL MIPAS PAN retrieval is based on an optimal estimation scheme in logarithmic parameter space, while the IMK MIPAS PAN retrieval consists of inversion of level-1B spectra to vertical profiles of atmospheric state parameters by constrained non-linear least squares fitting in a global-fit approach. The constraint is implemented as a firstorder Tikhonov regularization with an all-zero a priori profile. The two MIPAS retrieval schemes are discussed in more detail by Moore and Remedios (2010) and Glatthor et al. (2007), respectively, and compared in Sect. 3.2. We investigate the PAN data between the two retrieval processes and then also compare with observations from ACE-FTS.

MIPAS flew on board the ESA Envisat satellite and obtained data between 2002 and 2012. It was a limb-viewing instrument with an orbit height of $800 \mathrm{~km}$, which measured atmospheric gases in the mid-IR $\left(685-2410 \mathrm{~cm}^{-1}\right.$; Fischer et al., 2008). It had a descending equatorial local time crossing (LT) of 10:00 and approximately 14.4 orbits per day resulting in approximately 1400 profiles each day. The measurements, in reduced resolution nominal mode, had 27 tangential altitudes per limb scan. The lowermost (uppermost) tangent altitudes ranged approximately from $5 \mathrm{~km}(70 \mathrm{~km})$ near the poles to $12 \mathrm{~km}(77 \mathrm{~km}$ ) at the equator (Wiegele et al., 2012).

The ACE-FTS instrument, onboard the SCISAT satellite, is a limb-viewing instrument using solar occultation to measure atmospheric spectra over the IR region $750-4400 \mathrm{~cm}^{-1}$ continuously at high spectral resolution $\left(0.02 \mathrm{~cm}^{-1}\right)$. It can make measurements from 5 to $150 \mathrm{~km}$ in altitude with a field of view of about $3 \mathrm{~km}$ and can record up to 30 occultations (sunrise and sunset) per day (Bernath et al., 2005; Tereszchuk et al., 2013). Therefore, the spatial coverage of ACE-FTS is less than that of MIPAS, but it has similar vertical resolution.

We use aircraft measurements of PAN and its precursors to assess the skill of the model in the lower atmosphere where MIPAS does not retrieve PAN. We use aircraft data from the Aerosol, Radiation, and Cloud Processes affecting Arctic Climate (ARCPAC; Brock et al., 2011) project (31 March19 April 2008, 22 June-12 July 2008) and the Arctic Research of the Composition of the Troposphere from Aircraft and Satellites (ARCTAS; Jacob et al., 2010) mission (A, B,

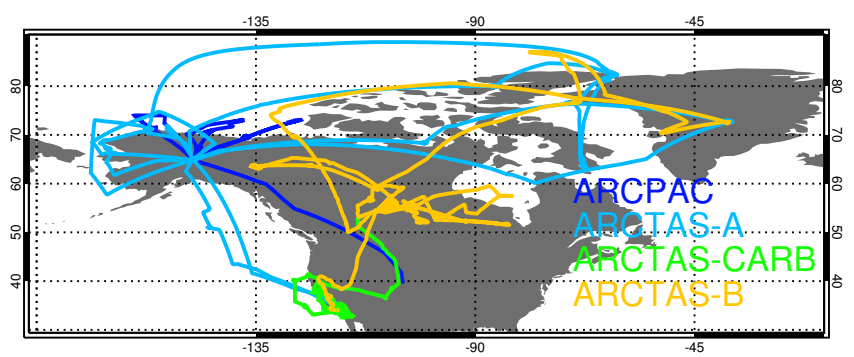

Figure 1. Map of the flight paths of the ARCPAC and ARCTAS aircraft campaigns in 2008 used to evaluate TOMCAT PAN and precursor species. See text for more details.

and CARB; 1 April-19 April 2008, 18 June-13 July 2008) over North America and Greenland to compare directly to TOMCAT in time and space. The flight tracks of the campaigns are shown in Fig. 1. We also compare TOMCAT with aircraft measurements of PAN from the multi-year regional aircraft composite dataset compiled by Emmons et al. (2000).

\subsection{TOMCAT 3-D model}

In this study we use the TOMCAT three-dimensional (3-D) offline CTM (e.g. Chipperfield et al., 1993; Stockwell and Chipperfield, 1999; Chipperfield, 2006). The model is forced using winds, temperature, and humidity from European Centre for Medium-Range Weather Forecasts (ECMWF) ERAInterim meteorological analyses. The standard model uses 82 advected tracers and 229 gas-phase reactions (Emmons et al., 2015), which includes the extended tropospheric chemistry (ExTC) scheme used by Richards et al. (2013).The VOC degradation chemistry scheme incorporates the oxidation of monoterpenes, $\mathrm{C} 2-\mathrm{C} 4$ alkanes, toluene, ethene, propene, acetone, methanol, and acetaldehyde, which was implemented by Monks (2011). The model chemistry scheme includes the Mainz condensed isoprene oxidation mechanism (MIM) (Pöschl et al., 2000). TOMCAT also includes heterogeneous $\mathrm{N}_{2} \mathrm{O}_{5}$ hydrolysis using online size-resolved aerosol from the Global Model of Aerosol Processes (GLOMAP) model (Mann et al., 2010). Aerosol types have individual uptake coefficients as parameterized by Evans and Jacob (2005), with the exception of dust which is based on Mogili et al. (2006). Short-lived species (e.g. OH) are not advected and assumed to be in photochemical steady state. Tracer advection by the resolved winds is performed using the scheme of Prather (1986). Sub-grid scale transport is performed using the Tiedtke convection scheme (Tiedtke, 1989; Stockwell and Chipperfield, 1999) and the Holtslag and Boville (1993) parameterization for turbulent mixing in the boundary layer following the method of Wang et al. (1999). Where available, kinetic data are taken from IUPAC (http://www. iupac-kinetic.ch.cam.ac.uk) and for other reactions, we use the Leeds Master Chemical Mechanism (MCM). The model anthropogenic emissions come from the Streets v1.2 inven- 


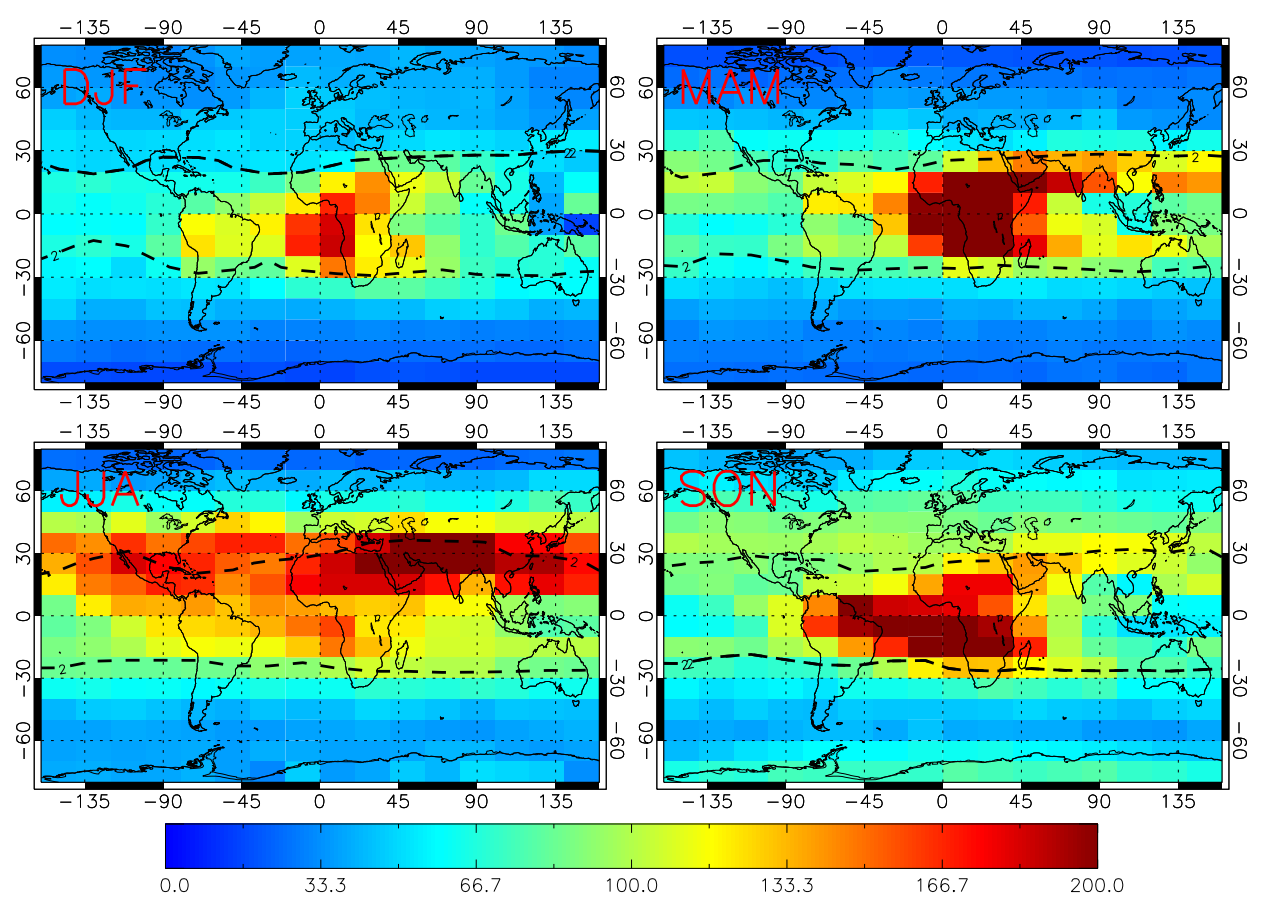

Figure 2. MIPAS PAN (pptv) from the IMK retrieval at $150 \mathrm{hPa}$ for 2007-2008 in December-January-February (DJF), March-AprilMay (MAM), June-July-August (JJA), and September-October-November (SON). The black dashed lines show the dynamical tropopause (defined as \pm 2 PVU) based on ERA-Interim data.

tory (provided by D. Streets (Argonne National Lab)), which is a composite of several regional emissions inventories (Emmons et al., 2015). The MACCity inventory (Granier et al., 2011) is used for the natural emissions, and biomass burning emissions come from the Global Fire Emissions Database (GFED) v3.1 inventory (Randerson et al., 2013). The model was initialized at the start of 2006, using a restart (initialization) file from previous simulations, which resulted in a model spin-up period of 1 year.

In order to compare TOMCAT with MIPAS, the model global fields were sampled at each individual MIPAS profile location and matched in time to the nearest $3 \mathrm{~h}$. The resulting TOMCAT profiles were then interpolated in the vertical to the retrieved pressure grid so the MIPAS averaging kernels (AKs) could be applied. This accounts for the satellite sensitivity to retrieving PAN in the atmosphere and allows for like-for-like comparisons. Both retrieval methods for UoL and IMK have MIPAS AKs with peak sensitivity between approximately 10-15 km (Wiegele et al., 2012; Moore and Remedios, 2010). The UoL (Eq. 1) and IMK (Eq. 2) MIPAS AKs are applied as follows:

$y=e^{A\left(\ln x-\ln x_{\mathrm{a}}\right)+\ln x_{\mathrm{a}}}$

$y=A \cdot x$,

where $y$ is the modified TOMCAT PAN retrieval, $A$ is the AK matrix, $x_{\mathrm{a}}$ is the a priori, and $x$ is the original model PAN profile. In the IMK retrieval process, the a priori used (Eq. 2) is zero. The UoL AKs are applied to the TOMCAT profiles in log space because their PAN profiles are retrieved in log space. Finally, both the TOMCAT and MIPAS profiles were averaged onto a horizontal grid of $20^{\circ}$ longitude by $10^{\circ}$ latitude for the 2-year time period 2007-2008. We perform TOMCAT simulations for 2007-2008, since MIPAS, ACEFTS, and aircraft data are available for this period.

\section{Results}

\subsection{Satellite PAN distributions}

Figures 2 and 3 show IMK and UoL MIPAS PAN at $150 \mathrm{hPa}$ in December-January-February (DJF), March-April-May (MAM), June-July-August (JJA), and September-OctoberNovember (SON) for 2007-2008. The black dashed line represents the dynamical tropopause ( \pm 2 PVU), based on ERAInterim potential vorticity data. Figure 4 shows the IMK minus UoL difference in these fields. In all seasons, this dynamical tropopause is at approximately $30^{\circ} \mathrm{N}$ and $30^{\circ} \mathrm{S}$ at $150 \mathrm{hPa}$. The largest PAN concentrations (>100 pptv) are typically in the tropical regions (i.e. upper troposphere). The lowest concentrations at this altitude $(<100 \mathrm{pptv})$ tend to be in the lower stratosphere (LS).

For the IMK data (Fig. 2) the peak PAN concentrations (>200 pptv) occur over Africa in MAM and SON and over southern Asia in JJA. The African peak PAN concentrations are linked to biomass burning and extend from the northern to the southern subtropics in MAM but are shifted to southern 


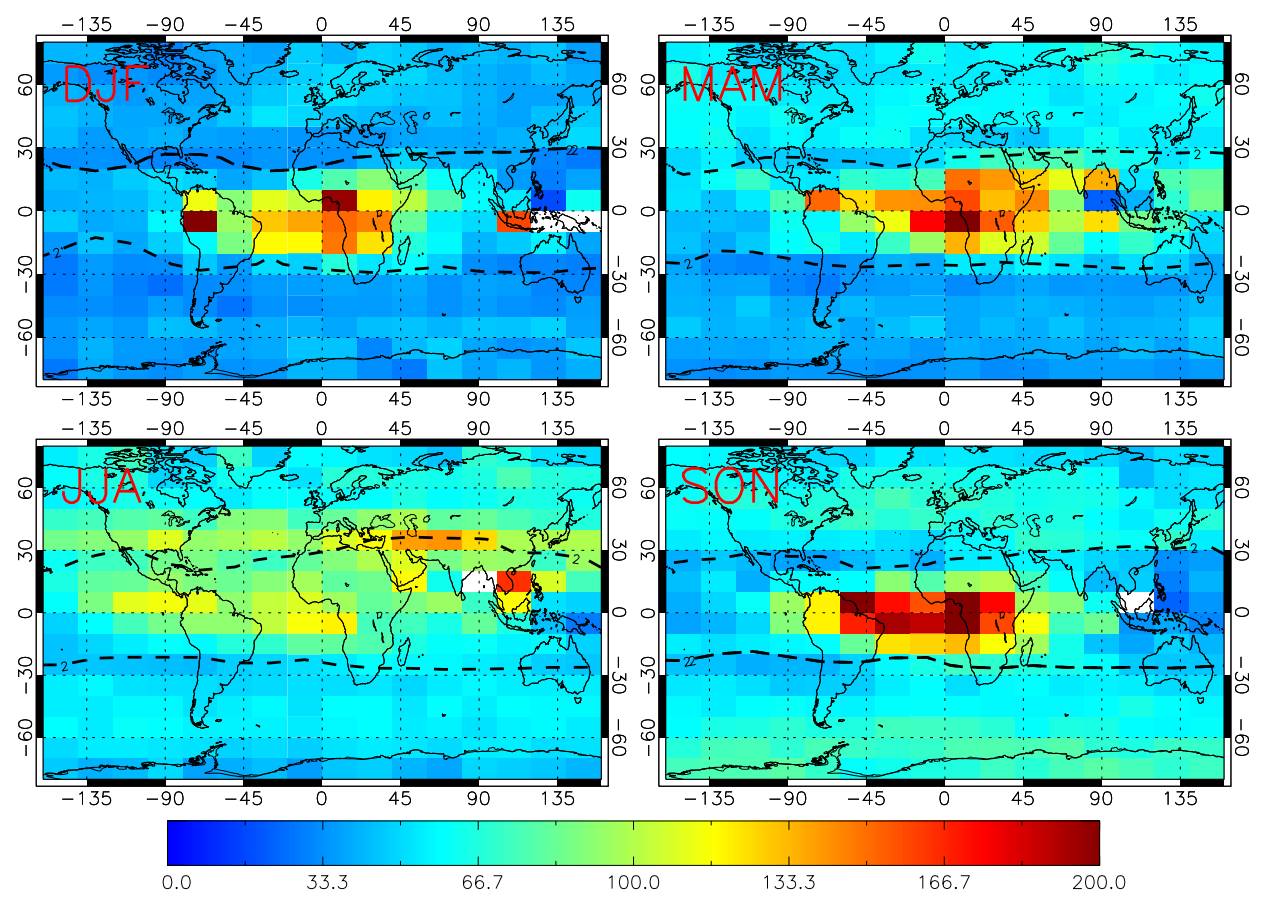

Figure 3. As Fig. 2 but for the UoL MIPAS retrieval.

Africa in SON. During SON, large PAN concentrations over the South Atlantic (>170 pptv) and along the SH dynamical tropopause (approximately $100 \mathrm{pptv}$ ) are linked to outflow from the African biomass burning plume and from lightninggenerated $\mathrm{NO}_{2}$ in the mid/upper troposphere. As shown by Belmonte Rivas et al. (2015), using a cloud slicing technique, there are significantly large sub-columns of $\mathrm{NO}_{2}$ in the midupper troposphere co-located with lightning activity. In addition, deep convection transports African biomass burning emissions efficiently to the UT in this region. Fischer et al. (2014) indicate that up to 50-60\% of PAN formation in the total column can be attributed to lightning $\mathrm{NO}_{2}$ emissions in their modelling study. IMK MIPAS retrievals of HCN (see Supplement), which is a long-lived tracer (5 months; Li et al., 2009) sourced from biomass burning, also shows a strong correlation with PAN in this region. Therefore, it appears that both lightning $\mathrm{NO}_{x}$ and biomass burning act as sources of PAN in this region. This is discussed further in the Supplement. In JJA, retrieved PAN concentrations in the UT range between 120 and $190 \mathrm{pptv}$ and cover the majority of the tropics including Africa, southern Asia, and the central Americas. This is probably linked to enhanced tropical upwelling of PAN from the lower troposphere, especially at $20-30^{\circ} \mathrm{N}$. Over India, in the summertime Asian monsoon, the dynamical tropopause has propagated northwards (by approximately $10^{\circ}$ ). Therefore, enhanced PAN in the UTLS is observed up to $40^{\circ} \mathrm{N}$ as shown by Fadnavis et al. (2014), resulting in the largest seasonal concentrations over 200 pptv.

Figure 3 shows that UoL PAN concentrations in the UT tend to be smaller over the tropics and the spatial struc- tures are also not as well defined as the IMK data. In the LS poleward of $40^{\circ} \mathrm{N}$ and S, UoL MIPAS PAN ranges from 20 to 70 pptv, which is $0-30$ pptv larger than the IMK MIPAS PAN (see Fig. 4). At $30-40^{\circ} \mathrm{N}$ and $\mathrm{S}$ in the LS, IMK MIPAS is larger by $0-20$ ppbv. Upper-tropospheric PAN predominantly ranges between 100 and $150 \mathrm{pptv}$, apart from the African biomass burning/lightning $\mathrm{NO}_{x}$ signals of approximately 160-200 pptv. In JJA, stronger vertical transport from the summertime Asian monsoon results in enhanced UT PAN concentrations (120-150 pptv) in comparisons to other seasons $(<100 \mathrm{pptv})$. However, this summertime Asian monsoon signal in the UoL PAN is not as prominent as in the IMK data.

Figure 4 shows the IMK-UoL MIPAS PAN differences at $150 \mathrm{hPa}$, where purple polygons indicate regions of significant differences between the two retrievals, which are defined when the mean retrievals plus or minus their uncertainty ranges do not overlap. The seasonal uncertainty ranges are based on the random and systematic errors in the retrieval process. Sources of retrieval error include measurement noise, interfering signals from other trace gases, errors in the temperature profile, instrument pointing, spectroscopic errors, calibration errors, and instrumental line of shape (Glatthor et al., 2007). The random errors reduce with time averaging by a factor of $1 / \sqrt{N}$, where $N$ is the number of observations. Systematic errors are not included in the product files, so we estimate them from Moore and Remedios (2010) and Glatthor et al. (2007). Moore and Remedios (2010) show that the UoL MIPAS PAN systematic errors range from 10 to $20 \%$ between 350 and $150 \mathrm{hPa}$ and 


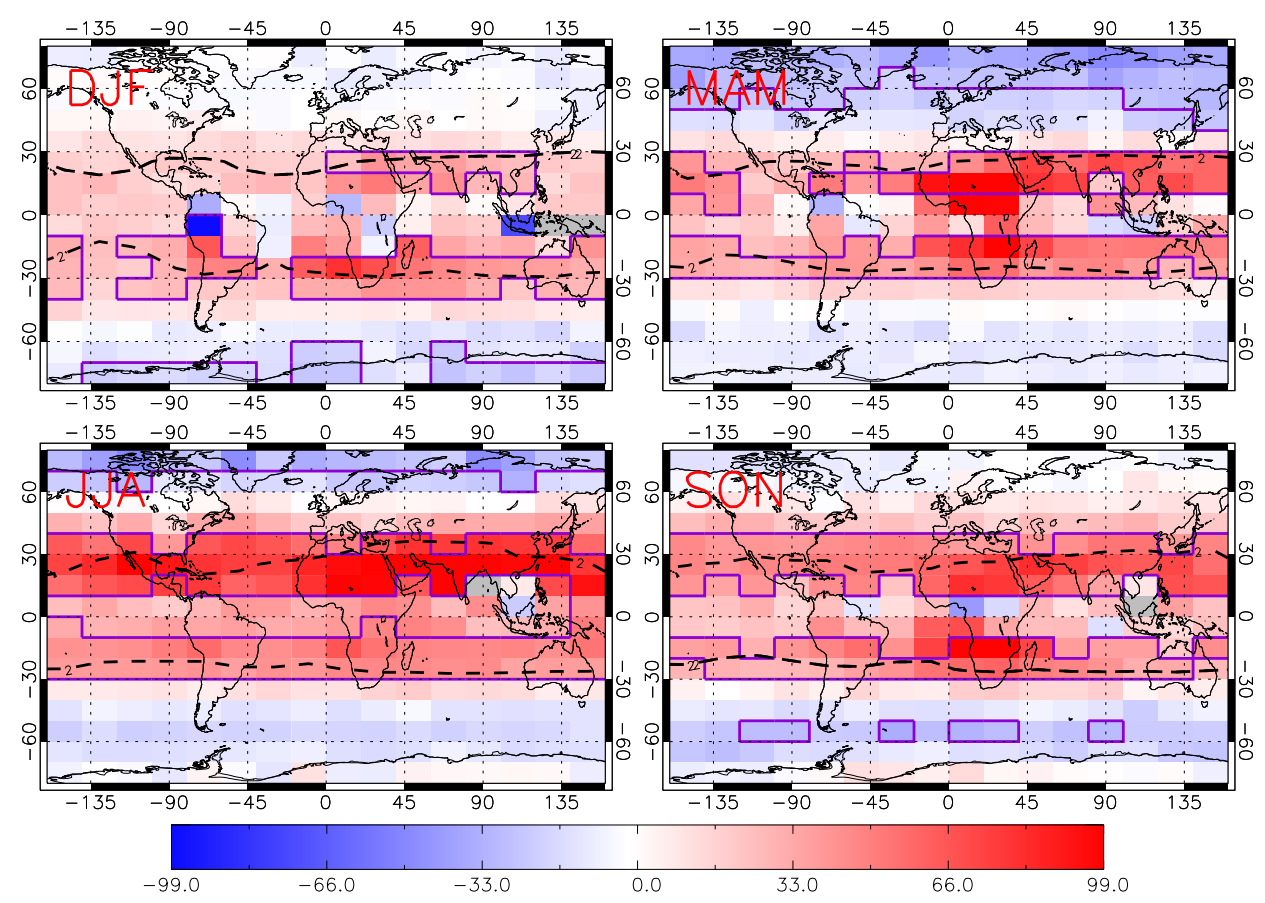

Figure 4. Difference in MIPAS PAN (pptv) from IMK retrieval minus UoL retrieval at $150 \mathrm{hPa}$ for 2007-2008 in DJF, MAM, JJA, and SON. Purple polygon regions show regions of significant differences, where the IMK and UoL retrieval uncertainty ranges do not overlap.

from 40 to $50 \%$ above $150 \mathrm{hPa}$. Therefore, we assume systematic errors of 20 and $50 \%$ at these altitudes, respectively. Glatthor et al. (2007) estimate the IMK MIPAS PAN systematic errors to be approximately 5-20 and 20-30\% between 350 and $150 \mathrm{hPa}$ and above $150 \mathrm{hPa}$, respectively. Therefore we assume systematic errors of 20 and $30 \%$ in these altitude ranges. For the ACE-FTS retrievals, Tereszchuk et al. (2013) suggest systematic errors of approximately $16 \%$.

Figure 4 shows that in the LS, the IMK PAN concentrations are $0-30$ pptv lower with significant differences in regions of the NH high latitudes in MAM and JJA and the SH high latitudes in DJF. IMK MIPAS PAN tends to be larger in the LS between 30 and $40^{\circ} \mathrm{N}$ and $\mathrm{S}$. In the UT, IMK tropical PAN concentrations are significantly larger (50-100 pptv) over northern Africa, South-east Asia, and in southern Africa. Therefore, the biggest differences are in locations of peak PAN concentrations. However, the IMK-UoL differences are not significant over the equator. In the midlatitudes, the two MIPAS datasets are in agreement with nonsignificant differences of -20 to 20 pptv.

To check the IMK and UoL MIPAS PAN differences at other levels, Figs. 5 and 6 show the zonal mean IMK and UoL PAN retrievals. The dashed lines again show the location of the dynamical tropopause. Stratospheric PAN concentrations predominantly range between 0 and $100 \mathrm{pptv}$ in both products. For the IMK PAN the peak zonal mean is 170 $220 \mathrm{pptv}$ near the northern midlatitude tropopause in JJA, associated with elevated PAN upwelling over India from the summertime Asian monsoon. In MAM and SON, peak PAN concentrations range from 120 to $160 \mathrm{pptv}$ at approximately $10-40^{\circ} \mathrm{N}$ and $20-30^{\circ} \mathrm{S}$, linked to biomass burning/lightning $\mathrm{NO}_{x}$ over central and southern Africa, respectively. In SON, there is enhanced PAN (70-90 pptv) between 70 and $90^{\circ} \mathrm{S}$ in the Antarctic lowermost stratosphere.

The UoL zonal mean PAN concentrations (Fig. 6) are smaller in the troposphere and in the vicinity of the dynamical tropopause, although they do have similar spatial patterns to the IMK data. In JJA, the peak UoL PAN near the northern midlatitude tropopause, linked to the summertime Asian monsoon, is between 100 and 170 pptv. Similar biomass burning/lightning $\mathrm{NO}_{x}$ signals occur in MAM and SON, but again the concentrations of between 90 and 150 pptv are lower than IMK data. The UoL retrievals also show high PAN concentrations between 200 and $100 \mathrm{hPa}$ in the SON southern high latitudes, but the magnitude is less pronounced than in the IMK data.

We have compared both MIPAS PAN retrievals to ACEFTS zonal mean profiles (Fig. 7) for 2007-2008. Although there is no validation of the ACE-FTS PAN product independent of the UoL MIPAS dataset considered here, we use it for further assessment of both MIPAS PAN products to try and evaluate the differences between them. In 2007-2008 there were approximately 5000 ACE-FTS PAN retrievals, which we co-located with corresponding MIPAS retrievals. For this comparison each MIPAS retrieval had to be within $6 \mathrm{~h}$ and $1000 \mathrm{~km}$ of the ACE-FTS retrievals.

In the tropical regions $\left(30^{\circ} \mathrm{S}-30^{\circ} \mathrm{N}\right)$, the UoL MIPAS PAN and ACE-FTS PAN concentrations are similar, between 

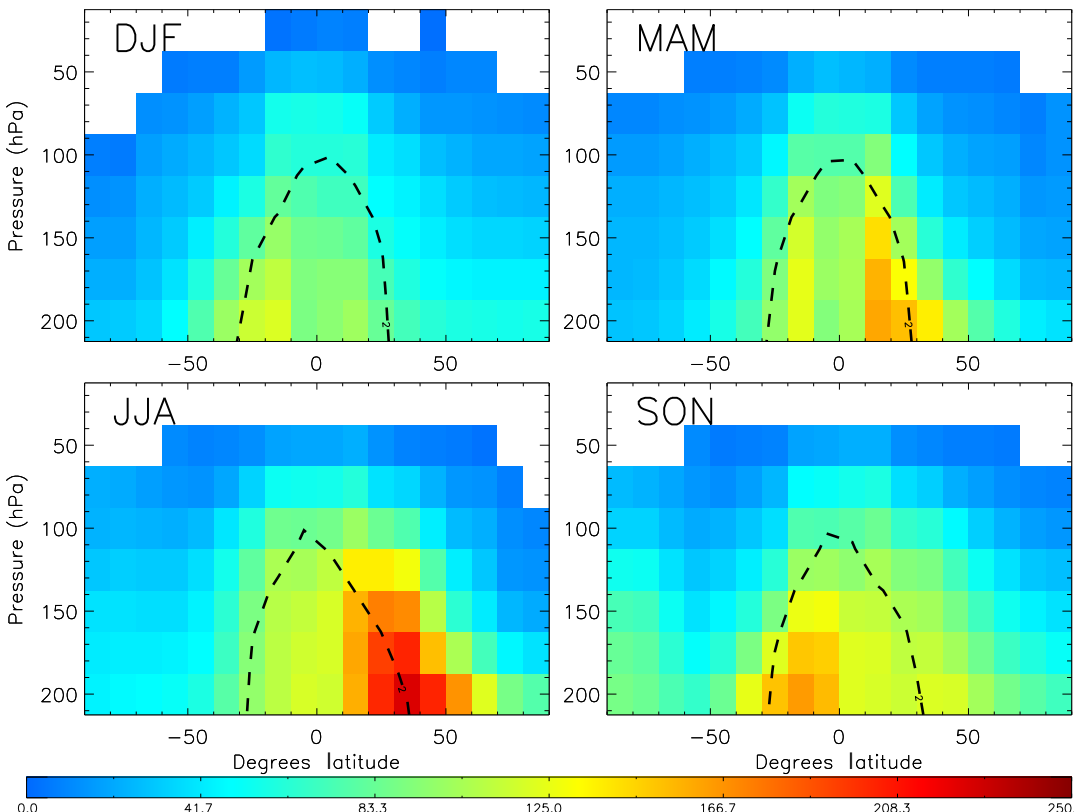

Figure 5. Zonal mean MIPAS PAN (pptv) from the IMK retrieval for 2007-2008 in DJF, MAM, JJA, and SON. The black dashed lines show the dynamical tropopause (defined as \pm 2 PVU) based on ERA-Interim data.
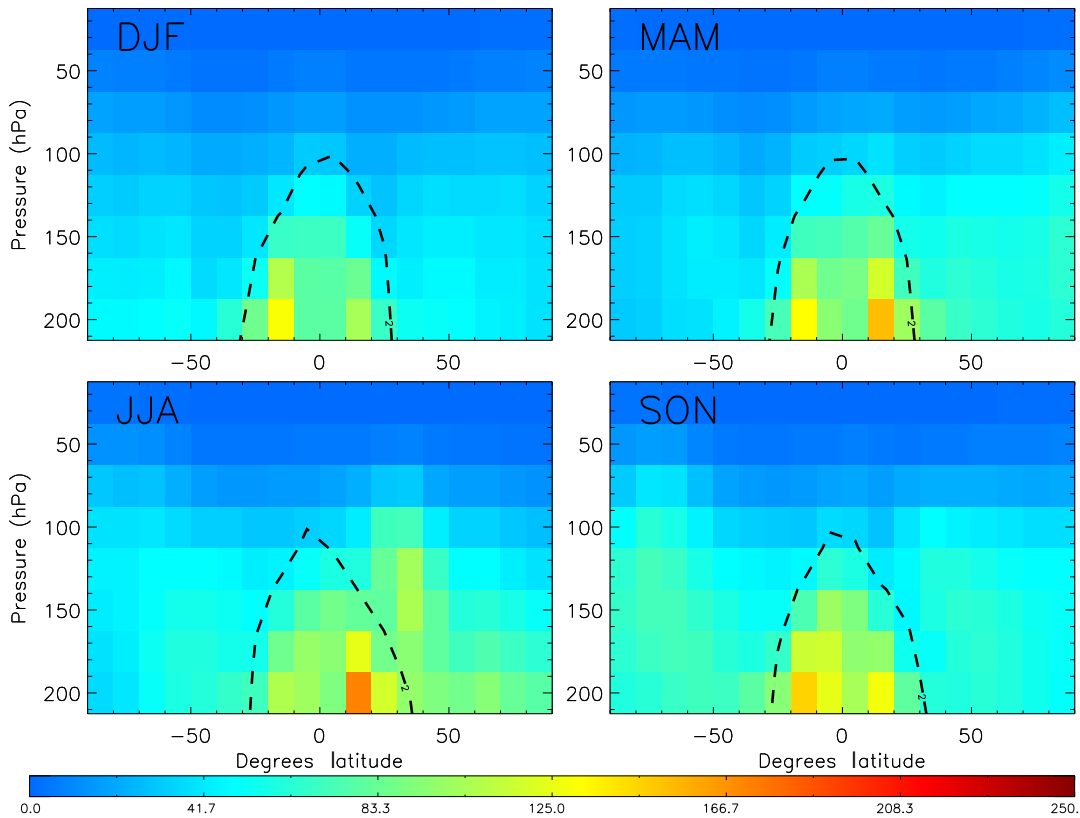

Figure 6. As Fig. 5 but for the UoL MIPAS retrieval.

70 and $90 \mathrm{pptv}$ at $200 \mathrm{hPa}$; IMK MIPAS tends to larger (> 100 pptv). However, the IMK MIPAS and ACE-FTS PAN profiles converge in the LS and the UoL MIPAS PAN is lower by $20-30 \mathrm{pptv}$. At $30-60^{\circ} \mathrm{N}$ and $\mathrm{S}$, the IMK MIPAS PAN is higher than the other products by $20-40$ pptv between 200 and $175 \mathrm{hPa}$. At $150-100 \mathrm{hPa}$, all three vertical profiles range between 30 and $50 \mathrm{pptv}$. Above $100 \mathrm{hPa}$, ACE-FTS PAN overestimates MIPAS PAN by about 20-30 pptv as the two MIPAS profiles converge. However, MIPAS sensitivity is reduced at these altitudes and PAN retrievals are heavily dependent on the a priori. Finally, between $60-90^{\circ} \mathrm{N}$ and $\mathrm{S}$, where the concentrations are generally the lowest globally, there is little difference in the MIPAS profiles at $200 \mathrm{hPa}$ (ACE-FTS PAN is lower by 20 pptv at $60-90^{\circ} \mathrm{S}$ ). Between $150-75 \mathrm{hPa}$, the UoL MIPAS PAN concentrations are larger than the IMK values by $10-40$ pptv, with mixed agreement 

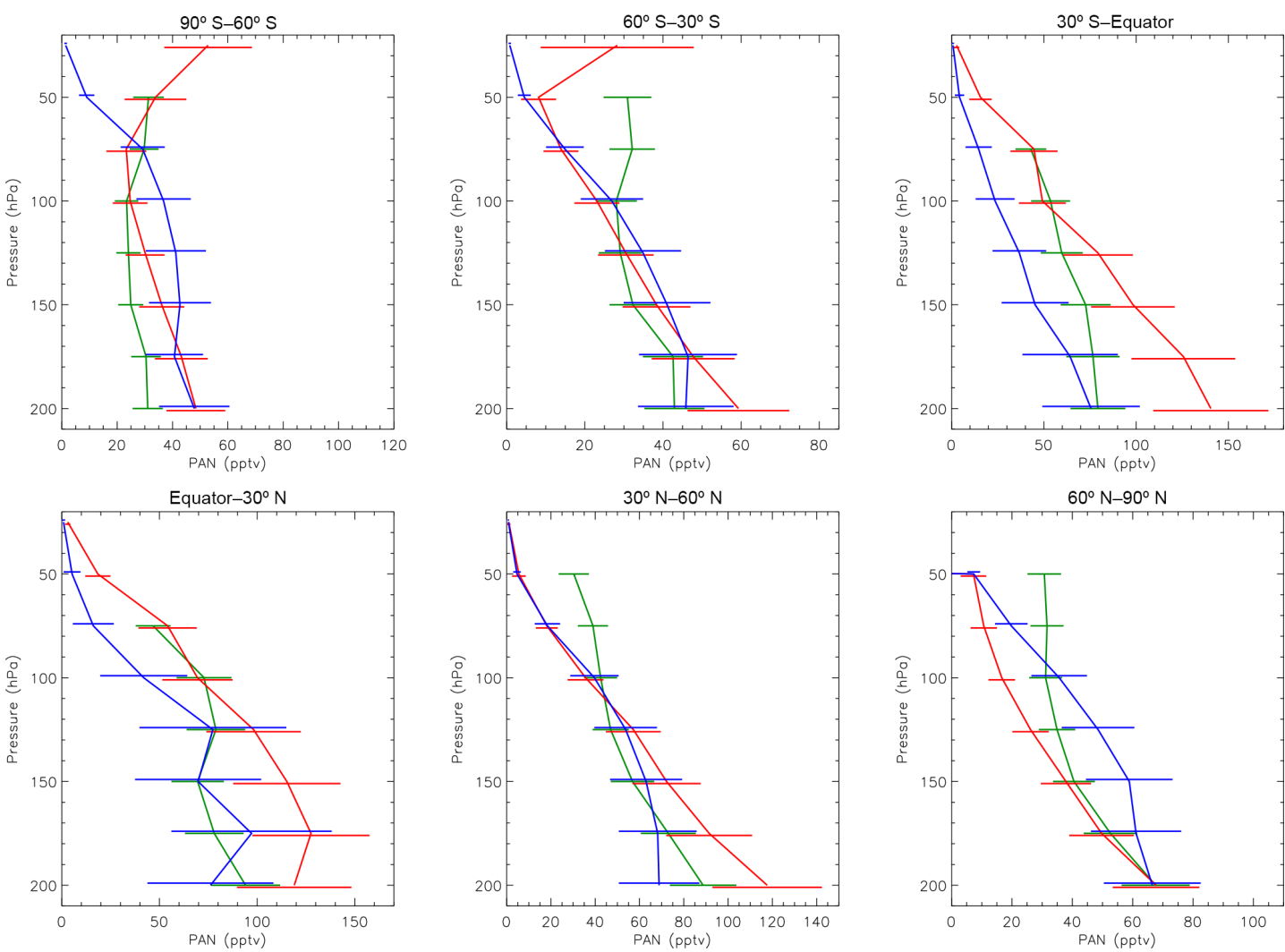

Figure 7. Zonal mean profiles of PAN (pptv) averaged within different latitude bands for 2007-2008 from ACE-FTS (green line), IMK MIPAS (red), and UoL MIPAS (blue). Horizontal lines give the satellite uncertainty ranges. MIPAS retrievals have been co-located with ACE-FTS retrievals.

with the ACE-FTS PAN profiles in this altitude range. Above $75 \mathrm{hPa}$, there are large differences ( $50 \mathrm{pptv}$ ) between the IMK and UoL MIPAS PAN in the Southern Hemisphere. Here, the IMK MIPAS and ACE-FTS PAN profiles are in better agreement. In the Northern Hemisphere, both MIPAS products are in better agreement as the ACE-FTS PAN profile is $10-30$ pptv higher. Overall, despite the differences in the satellite PAN retrievals, all three products largely fall within the uncertainty ranges of each other.

\subsection{IMK-UoL differences}

Reasons for the differences between the IMK and UoL MIPAS PAN retrievals are potentially linked with the independent retrieval schemes. The UoL MIPAS Orbital Retrieval using Sequential Estimation (MORSE) scheme is an optimal estimation algorithm in logarithmic parameter space with PAN values from the MOZART 3-D model as constraints for the profile regularization. The IMK retrieval uses a firstorder Tikhonov regularization which constrains the differences between adjacent profile values towards small values, i.e. the constraint does not directly influence the profile values but rather the smoothness of the retrieved profile. Furthermore the two schemes use different forward models to calculate the radiative transfer. The IMK retrieval utilizes the Karlsruhe Optimized and Precise Radiative transfer Algorithm (KOPRA), while the MORSE scheme uses a version of the Reference Forward Model (RFM). A previous study (Glatthor et al., 1999) found that differences in the KOPRA and RFM interpolation approach for cross-section data gave differences in CFC-12 results of up to $30 \mathrm{nW} /\left(\mathrm{cm}^{2} \mathrm{srcm}^{-1}\right)$, which is comparable with the MIPAS noise-equivalent spectral radiance (NESR) in band A. PAN data are in the form of cross sections, although no equivalent test has been carried out for this species to test the expected radiance difference.

Alongside the forward models used there are also several differences in the retrieval set-up, which may account for some of the differences. The optimized resolution MIPAS data are measured on levels which are approximately $1.5 \mathrm{~km}$ apart in the UTLS. The MORSE state vector retrieves on the same $1.5 \mathrm{~km}$ spaced levels, whereas the IMK retrieval is on a finer $1 \mathrm{~km}$ grid. The IMK retrieval also uses one single retrieval microwindow $\left(775-800 \mathrm{~cm}^{-1}\right.$, but it is split into two sub-microwindows of 775-787 and 794.5$800 \mathrm{~cm}^{-1}$ ), whereas the MORSE retrieval uses five smaller windows in the 777 to $798 \mathrm{~cm}^{-1}$ range, which are ordered in terms of simulated information content to use the window with the highest information content for the first fit. 
These are slightly different to the windows used in the full-resolution mode in Moore and Remedios (2010) and are (1) 784.9375 to $787 \mathrm{~cm}^{-1}$, (2) 779.5 to $784.125 \mathrm{~cm}^{-1}$, (3) 777.25 to $779.125 \mathrm{~cm}^{-1}$, (4) 794 to $795.75 \mathrm{~cm}^{-1}$, and (5) 796.0625 to $797.75 \mathrm{~cm}^{-1}$. Both schemes fit continua in the retrieval process and fit offsets to each retrieval microwindow.

Interfering species are also handled differently: MORSE performs sequential retrievals, meaning that each species is retrieved in turn. For the MORSE PAN, the order is $p, T$, $\mathrm{H}_{2} \mathrm{O}, \mathrm{O}_{3}, \mathrm{HNO}_{3}, \mathrm{ClONO}_{2}$, and $\mathrm{CCl}_{4}$ before retrieval of PAN. The IMK processor also performs sequential retrievals, but from these only the pre-fitted species $p, T, \mathrm{HNO}_{3}, \mathrm{ClO}$, CFC-11, $\mathrm{C}_{2} \mathrm{H}_{6}$, and $\mathrm{HCN}$ are used in the PAN retrieval, while $\mathrm{CH}_{3} \mathrm{CCl}_{3}, \mathrm{CCl}_{4}, \mathrm{ClONO}_{2}, \mathrm{HCFC}-22, \mathrm{O}_{3}, \mathrm{H}_{2} \mathrm{O}$, and $\mathrm{C}_{2} \mathrm{H}_{2}$ are fitted together with PAN in the same microwindow.

\subsection{Model-aircraft comparisons}

Figure 8 shows the comparisons between TOMCAT and the aircraft measurements from the ARCPAC and ARCTAS campaigns for CO, PAN, acetone, and acetaldehyde in 2008. TOMCAT output has been interpolated both spatially and temporally to the location and time of the observations. The observed and modelled median concentration in $50 \mathrm{hPa}$ pressure bins is used to give a vertical profile. The 25th and 75th percentiles for both the model and observations are shown to indicate the spread of the model and observations within each bin. For the ARCTAS data, results from two different measurements of acetone and acetaldehyde by different techniques (proton transfer reaction mass spectrometry, PTRMS, and trace organic gas analyser, TOGA) are shown.

When compared with the ARCPAC campaign, TOMCAT springtime $\mathrm{CO}$ is low throughout the troposphere, which is a common problem in global models at higher latitudes (Monks et al., 2015). However, there is also evidence of a plume of enhanced $\mathrm{CO}$ that is not captured by the model at $600 \mathrm{hPa}$. PAN is also clearly enhanced at about $600 \mathrm{hPa}$, which again is not captured by the model. During April 2008 there were unusually high emissions from biomass burning that were transported to the Arctic. The ARCPAC campaign targeted some of these plumes leading to enhanced measurements of several species (Warneke et al., 2010). The inability of the model to capture these enhancements is likely due to the biomass burning emissions used in the model or its coarse horizontal resolution, and it is difficult to draw any conclusions about TOMCAT PAN here.

In the ARCTAS summer campaigns (ARCTAS-B \& ARCTAS-CARB), TOMCAT successfully reproduces the aircraft $\mathrm{CO}$ profile. For PAN, the TOMCAT average profile is within the ARCTAS variability range apart from at $950 \mathrm{hPa}(+300 \mathrm{pptv}$, ARCTAS-B) and $800-750 \mathrm{hPa}$ ( -100 pptv, ARCTAS-CARB), but it captures UT PAN successfully. When compared with ARCTAS-A, TOMCAT significantly overestimates PAN by $150-200$ pptv between 950 and $700 \mathrm{hPa}$ and by $20-50 \mathrm{pptv}$ at $450-250 \mathrm{hPa}$. Between $700-450 \mathrm{hPa}$ and above $250 \mathrm{hPa}$, TOMCAT PAN is within the observational variability. TOMCAT acetaldehyde average profiles underestimate the ARCTAS-A, B, and CARB profiles in the mid-lower troposphere. Emmons et al. (2015) found that several models underestimated acetaldehyde from this campaign in spring (including TOMCAT), but in summer TOMCAT concentrations were on the low end of the model distribution. Acetone was also found to be low in these models in summer when compared with these data. However, in spring there was a wide range in acetone in the same models suggesting that the springtime low bias in acetone is a problem in TOMCAT. The models which had higher acetone also had lower PAN suggesting that TOMCAT may be too efficient at producing PAN during long-range transport events to the Arctic. If acetone sources were increased in the model, this would likely make PAN concentrations too high.

We also compare TOMCAT with the multi-year regional aircraft composite dataset compiled by Emmons et al. (2000), which allows for comparisons in other regions. Within this dataset, aircraft profiles for several geographic regions are constructed using data from several flights representing large spatial and temporal averages. TOMCAT output for 2007-8 was averaged over the same spatial regions and months as each of the aircraft profiles. Given the climatological nature of the aircraft profiles and the high degree of variability exhibited by tropospheric PAN, the aircraft profiles may not be truly representative of the distribution in a given region for the simulated period used in this study. With this in mind, profiles were selected for comparison which are likely to be representative of background concentrations in a particular region. A disadvantage with this method is the temporal difference between the TOMCAT runs and the Emmons et al. (2000) climatology.

In Fig. 9, TOMCAT reproduces the vertical structure of aircraft PAN in Hawaii but significantly overestimates PAN throughout the profile at Alaska. At Christmas Island, TOMCAT and aircraft data agree well in the lower-mid troposphere, but the model significantly overestimates PAN above $5 \mathrm{~km}$. Near the surface, TOMCAT is able to reproduce the low PAN concentrations where there are no sources. In the more anthropogenically polluted regions, e.g. Japan and China, the model struggles to simulate the larger near-surface PAN concentrations. In the boundary layer, model PAN increases with altitude, while aircraft profiles decrease. However, TOMCAT PAN is within the observational variability and captures the vertical structure of PAN above $2 \mathrm{~km}$. Near the US east coast, TOMCAT captures the near-surface concentrations (approximately 1000 pptv) but overestimates PAN in the lower-mid troposphere by $200-500 \mathrm{pptv}$. In the regions of strong biomass burning signals, TOMCAT captures the vertical structure within the aircraft uncertainty range at the West African coast but significantly underestimates PAN in east Brazil. 

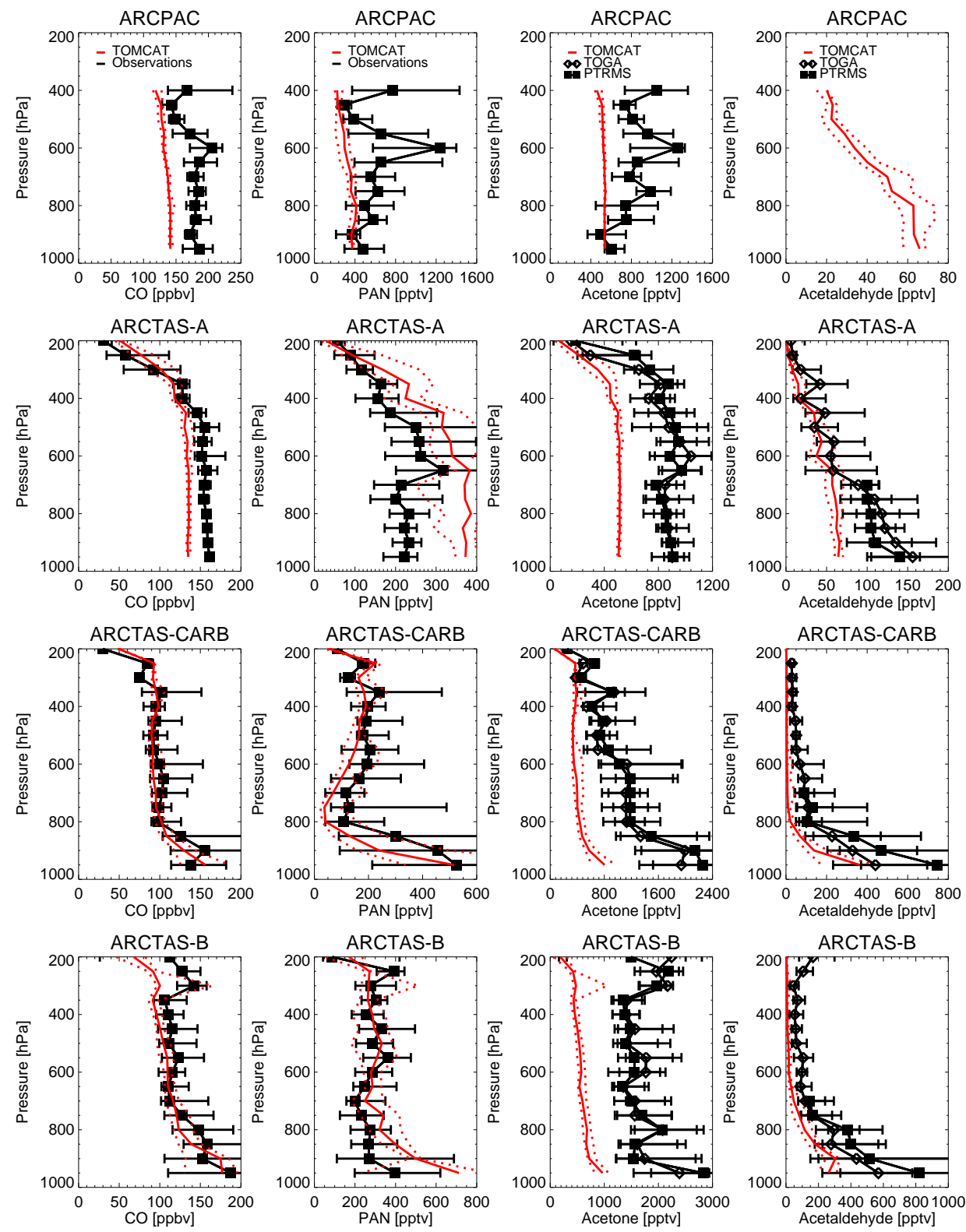

Figure 8. Observed profiles of CO (ppbv), PAN, acetone, and acetaldehyde (pptv) for 2008 from the ARCPAC and ARCTAS campaigns compared to results from the TOMCAT model sampled in the same location. The black lines give the median observed concentration and the error bars give the 25 th and 75 th percentiles. The solid red line gives the median modelled concentration, and the dotted lines give the 25 th and 75 th percentiles.

Overall, the above figures show that TOMCAT can generally reproduce UT PAN observed from the ARCTAS campaign in the spring and summer of 2008, although these comparisons are limited to North America. Comparisons with the Emmons et al. (2000) climatology show that TOMCAT can capture the majority of the PAN vertical profiles in various global background regions. Therefore, we have confidence in the model and use it as a tool to assess differences in the IMK and UoL MIPAS PAN products.

\subsection{TOMCAT-satellite comparisons}

At $150 \mathrm{hPa}$, TOMCAT, with the MIPAS AKs applied (Figs. 10 and 11), has maximum PAN concentrations in the UT ( $>100$ pptv) over the tropics and minimum values $(<100$ pptv $)$ in the LS over the mid-high latitudes. Note that the TOMCAT PAN distributions at $150 \mathrm{hPa}$ in Figs. 10 and 11 are slightly different due to the application of the IMK and UoL MIPAS AKs. Typically, with the application of the IMK MIPAS PAN AKs, the TOMCAT PAN concentrations 

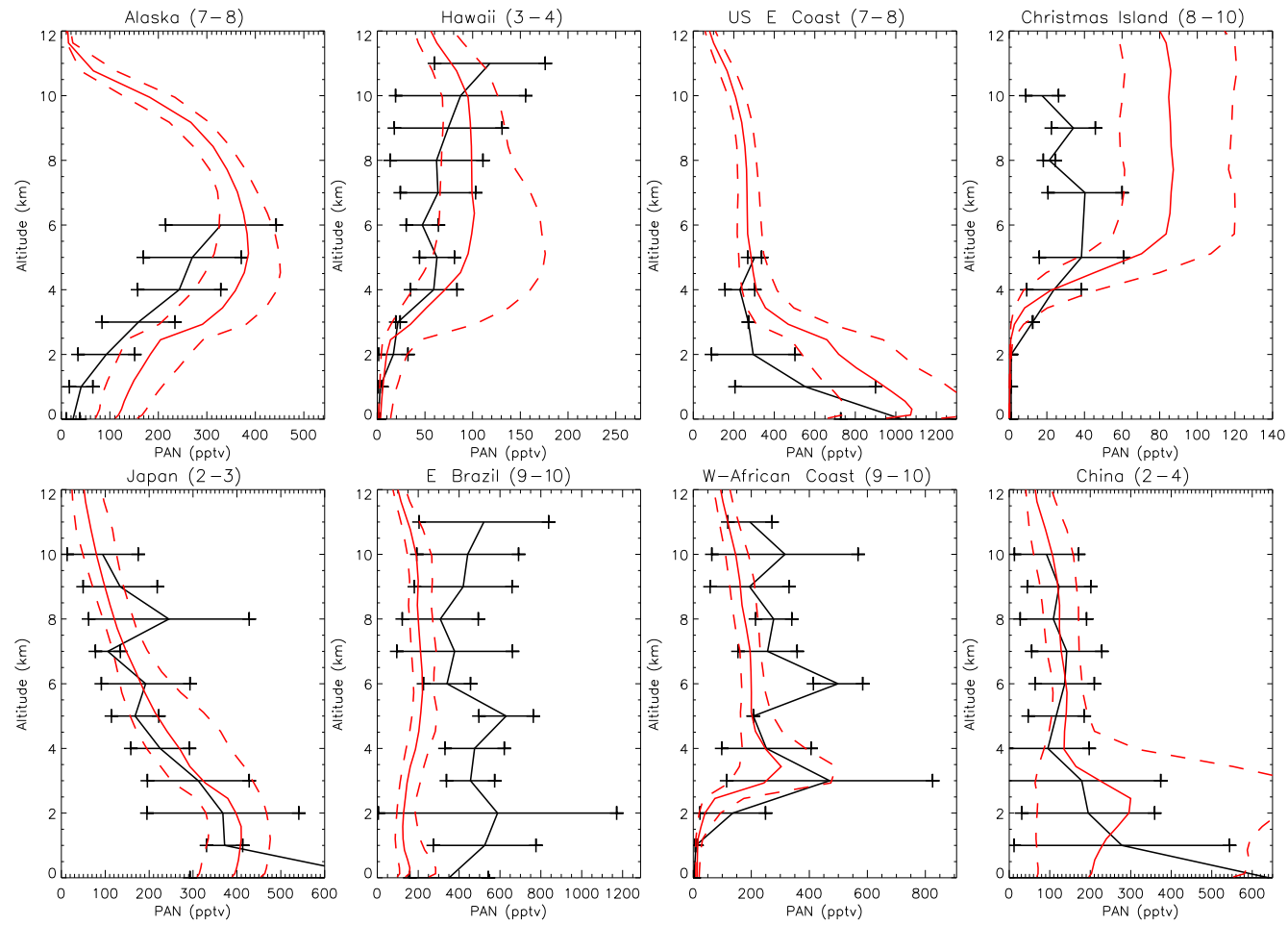

Figure 9. Vertical profiles of PAN from the Emmons et al. (2000) aircraft climatology (black) and the TOMCAT model (red) for eight different regions given in the panel titles The numbers in the title represent the months sampled. The TOMCAT PAN data have been averaged over the same locations and times as the measurements. The horizontal error bars are the observational standard deviations, and the dashed lines are the model 25 th and 75 th percentiles.

are larger in the UT and lower in the LS when compared to TOMCAT PAN concentrations with the UoL AKs applied. In DJF, TOMCAT has elevated PAN (130-150 pptv) over central Africa like MIPAS, but the largest model PAN values are over tropical South America and South-east Asia (150$180 \mathrm{pptv})$. Such features are not as noticeable in the MIPAS datasets. In MAM, TOMCAT reproduces the biomass burning PAN signal (120-150 pptv) over central Africa, although this is lower than IMK and UoL PAN values in this region. In JJA, TOMCAT has elevated PAN concentrations over India linked to convective upwelling of PAN into the UTLS from the summertime Asian monsoon. This signal is clearly seen in the IMK MIPAS PAN data, but less so in the UoL data. The peak TOMCAT PAN concentrations (170-200 pptv) are over the Middle East, which is also seen by the MIPAS PAN datasets. In SON, TOMCAT misses PAN over the South Atlantic, which is likely associated with biomass burning outflow and lightning $\mathrm{NO}_{x}$ from southern Africa. In the IMK and UoL PAN products, PAN concentrations range from 150 to $200 \mathrm{pptv}$, while they are only $100-120 \mathrm{pptv}$ in the TOMCAT PAN distribution. This low model bias means that it is difficult to use the model to diagnose the relative contributions of biomass burning and lightning $\mathrm{NO}_{x}$ to the formation of PAN in this region and season.
Figures 12 and 13 show the differences between the satellite observations and TOMCAT simulations for the IMK and UoL retrievals, respectively. Again the purple polygon regions show where the differences are significant, i.e. where the absolute model-satellite mean bias (MB) is greater than that of the observational error. In DJF, TOMCAT significantly overestimates IMK PAN by 30-60 pptv throughout the tropical UT region, apart from Africa. Though the largest differences are over tropical South America and South-east Asia. There are significant negative biases of -20 to 0 pptv in the LS, which occur in all seasons. In MAM, the largest differences of -90 to $-60 \mathrm{pptv}$ are over central Africa. Though TOMCAT captures the biomass burning signal in MAM (Fig. 10), it still significantly under-predicts the IMK MIPAS PAN. In JJA and SON, TOMCAT significantly underestimates $(<-50$ pptv) IMK MIPAS PAN across the majority of the domain, especially in the northern midlatitudes and southern Africa and the South Atlantic.

When compared with the UoL MIPAS data (Fig. 13), TOMCAT generally underestimates PAN in the LS, while overestimating it in the UT. In MAM, JJA, and SON, TOMCAT is significantly biased by -40 to $0 \mathrm{pptv}$ in the LS. In DJF, this signal is reduced in the northern high latitudes and is positive in the southern high latitudes. The largest TOMCAT PAN underestimation of between -80 and $-50 \mathrm{pptv}$ is 

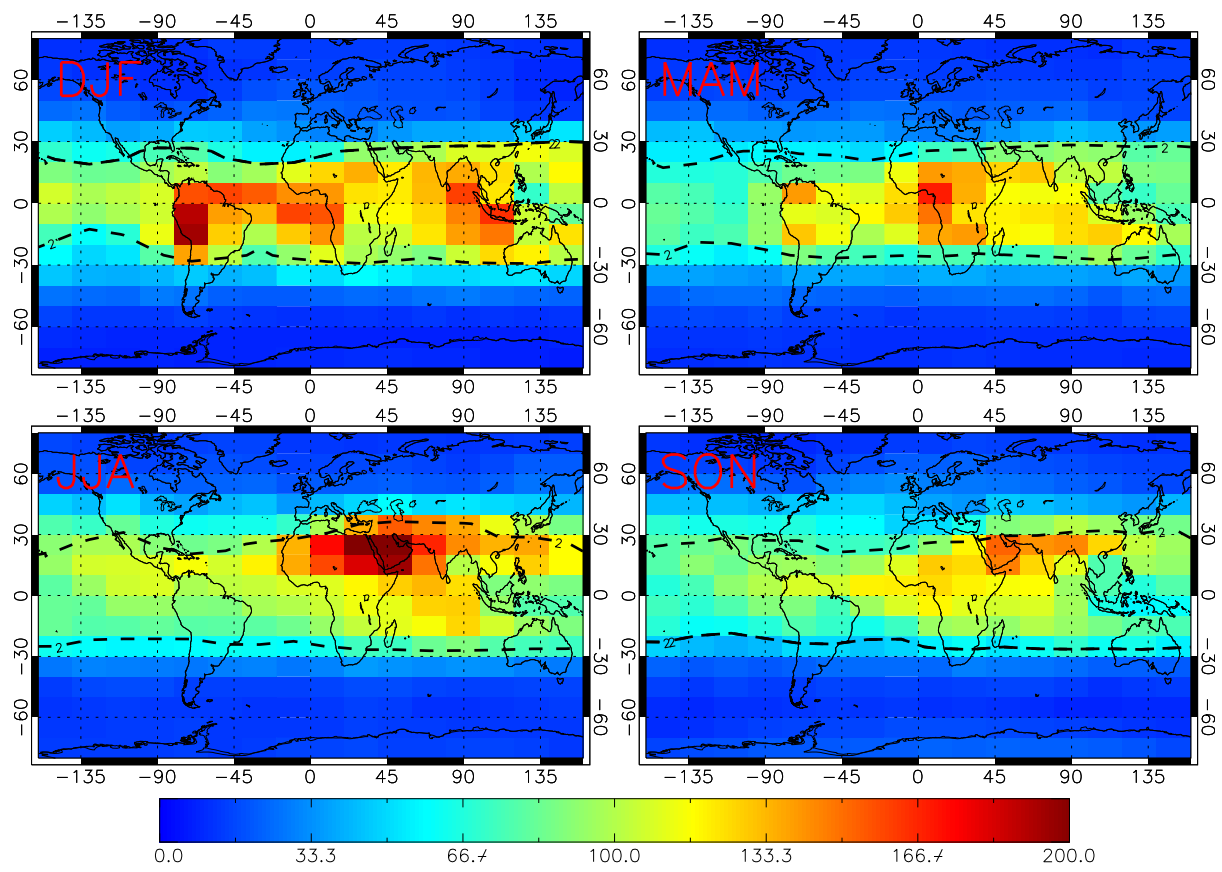

Figure 10. Mixing ratio of PAN (pptv) from the TOMCAT model (with the IMK averaging kernels applied) at $150 \mathrm{hPa}$ averaged over the periods DJF, MAM, JJA, and SON in 2007-2008.

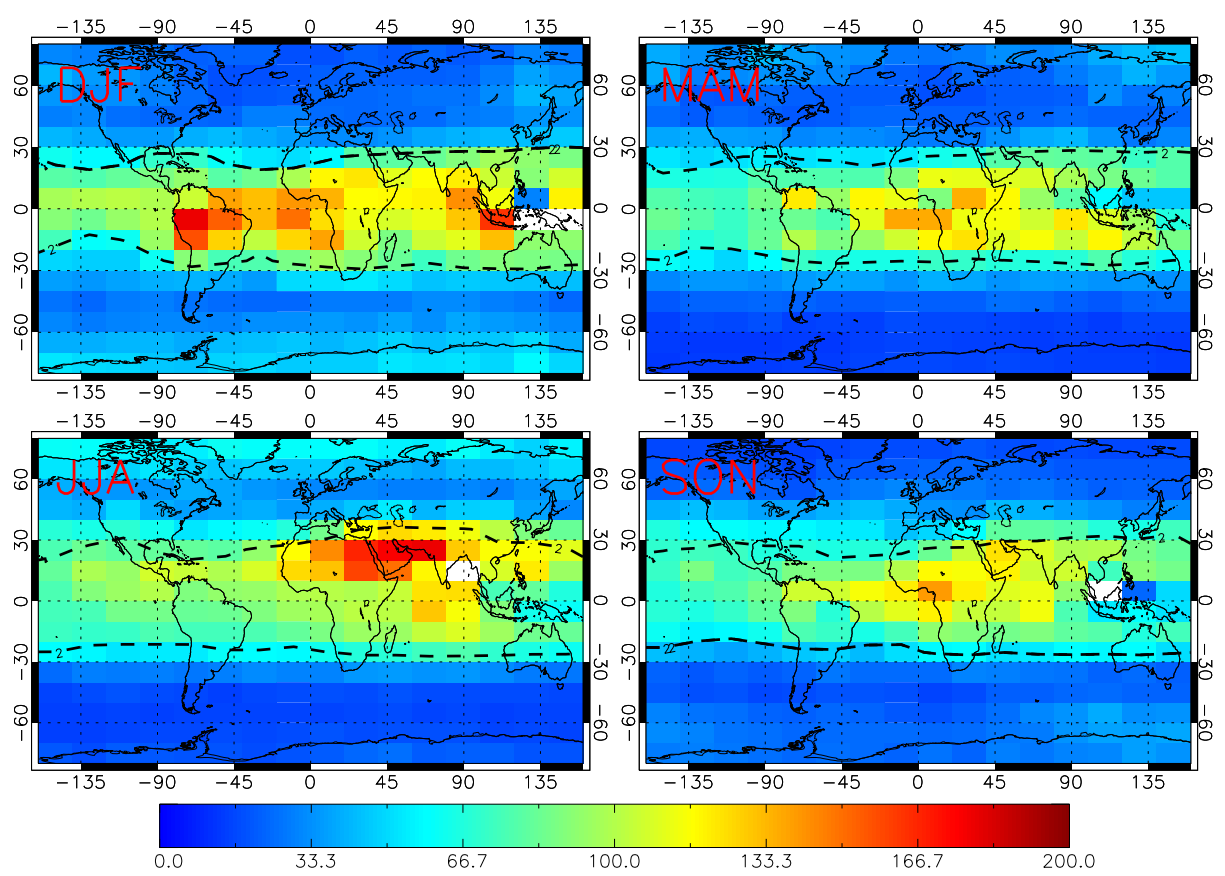

Figure 11. As Fig. 10 but for the application of the UoL averaging kernels to the TOMCAT model output.

in SON over southern Africa. Here, TOMCAT seems to be missing PAN produced from $\mathrm{NO}_{x}$ biomass burning and lightning emissions, which is seen in the IMK data. The large positive biases in DJF (30-70 pptv), also seen in Fig. 12, are over South-east Asia, the Pacific, and Central/South America. In
MAM, significant positive biases are typically between the equator and the southern dynamical tropopause.

Zonal mean TOMCAT PAN, with both sets of AKs applied, is shown in Figs. 14 and 15. In all seasons, PAN ranges between 0 and 50 pptv in LS and 50 and 100 pptv around the 


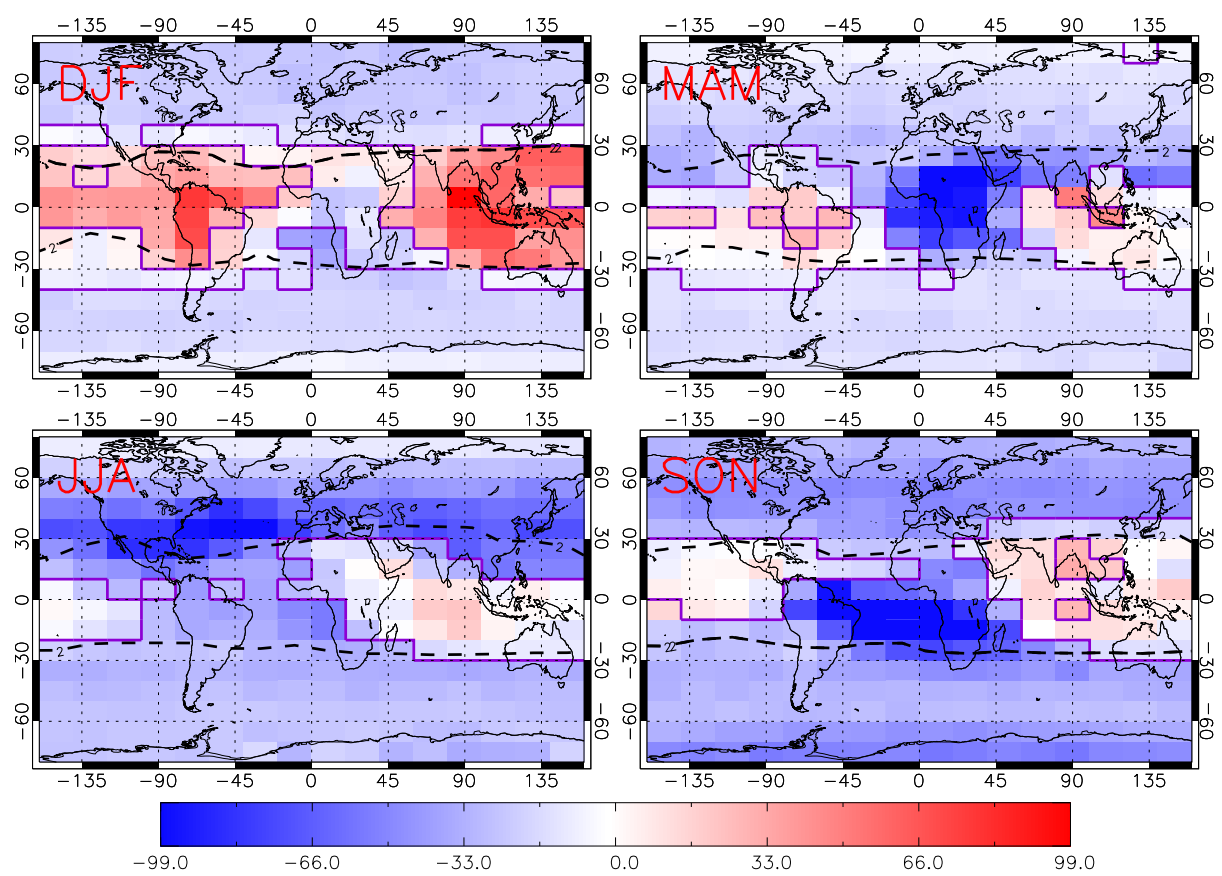

Figure 12. Difference in PAN (pptv) between the TOMCAT model (with IMK AKs applied) and observed IMK MIPAS PAN at $150 \mathrm{hPa}$ for 2007-2008 in DJF, MAM, JJA, and SON. Purple polygon areas show regions of significant differences, where the |TOMCAT - observations $>$ observational error.

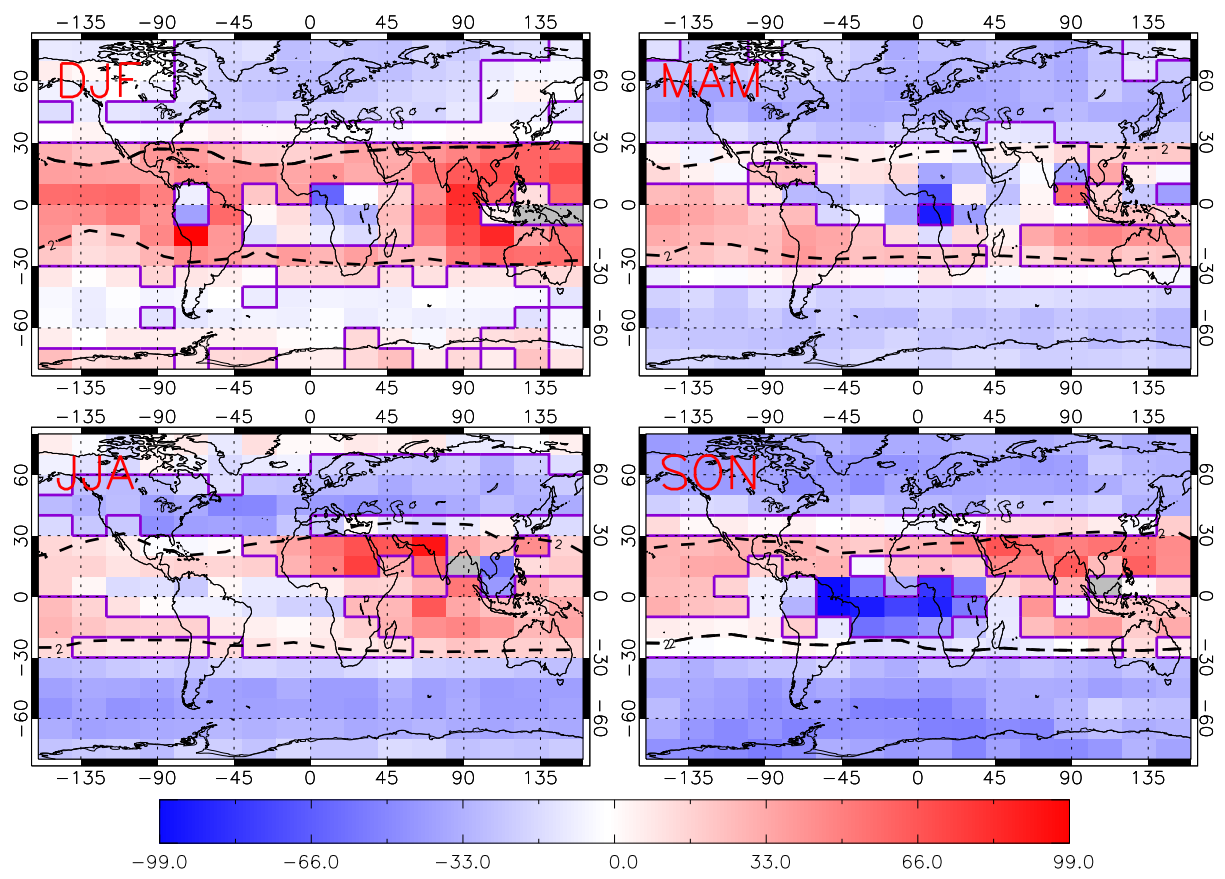

Figure 13. As Fig. 12 but for UoL MIPAS observations and application of the UoL averaging kernels to the TOMCAT model output.

tropopause. In the UT, TOMCAT PAN ranges between 100 and $150 \mathrm{pptv}$ in DJF, MAM, and SON. In JJA, peak PAN concentrations are larger and reach 160-180 pptv, linked to the summertime Asian monsoon. When compared with zonal mean MIPAS PAN, TOMCAT does not have the same el- evated concentrations associated with the MAM and SON African biomass burning signals. Similar to the $150 \mathrm{hPa}$ comparisons (Figs. 10 and 11), TOMCAT PAN concentrations with the IMK MIPAS PAN AKs applied are higher in the UT and lower in the LS than the UoL equivalent. 

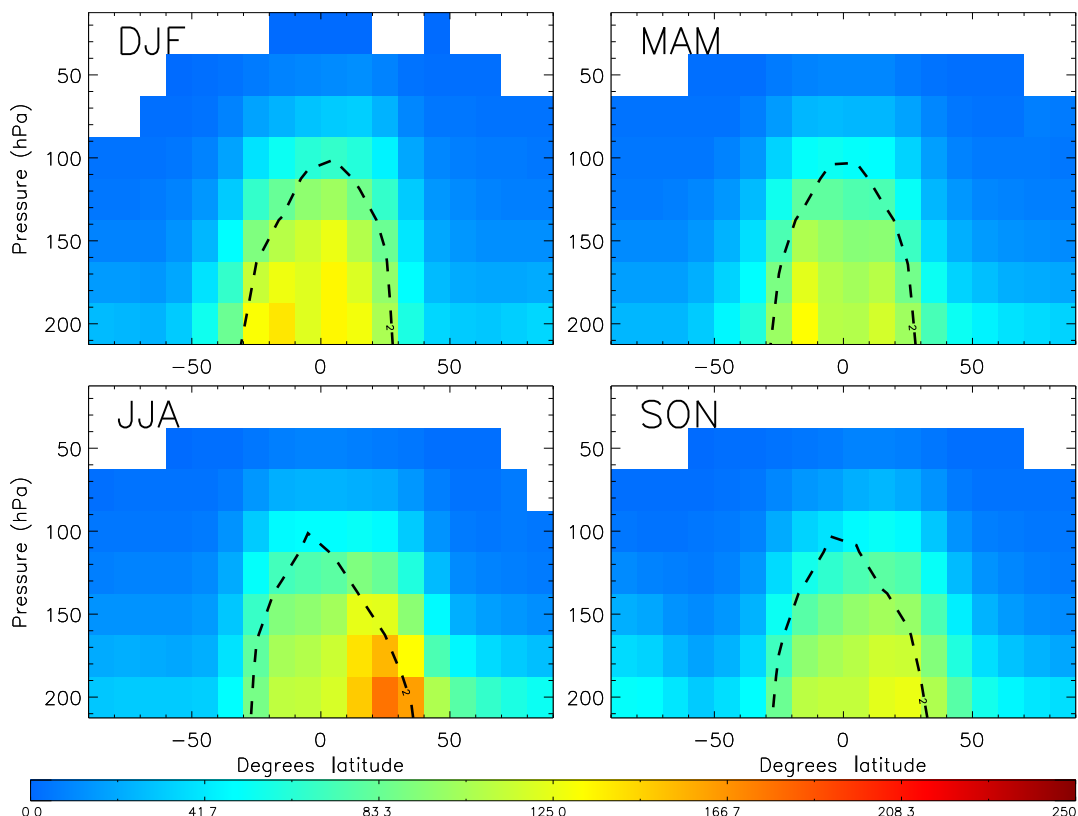

Figure 14. Zonal mean PAN (pptv) from the TOMCAT model (with IMK AKs applied) for 2007-2008 in DJF, MAM, JJA, and SON.
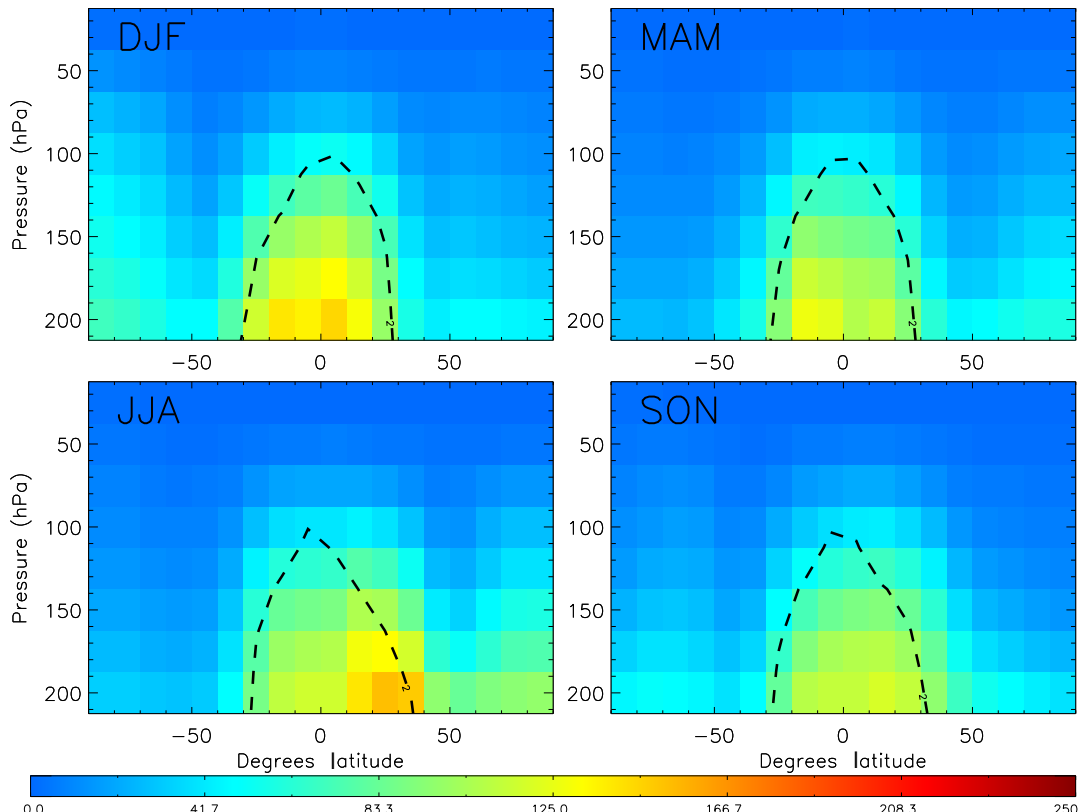

Figure 15. As Fig. 14 but for the application of the UoL averaging kernels to the TOMCAT model output.

The TOMCAT-satellite differences in zonal mean PAN are shown in Figs. 16 and 17. Here, the hatching shows regions of non-significant differences. As for the differences at $150 \mathrm{hPa}$, TOMCAT significantly underestimates IMK PAN by 10 to $>80 \mathrm{pptv}$ in the LS. In DJF, TOMCAT simulates higher PAN concentrations (0-50 pptv) than observed between 200 and $125 \mathrm{hPa}$ at $10^{\circ} \mathrm{S}-30^{\circ} \mathrm{N}$. Negative biases $(-50$ to $-40 \mathrm{pptv}$ ) around the $\mathrm{NH}$ and $\mathrm{SH}$ dynamical tropopause in MAM and SON, respectively, are linked to lower TOM-
CAT PAN concentrations in regions of biomass burning and peak lightning activity. In JJA, TOMCAT underestimates IMK MIPAS PAN throughout the midlatitudes between 200$100 \mathrm{hPa}$, as seen in Fig. 12. When compared with UoL MIPAS PAN, TOMCAT significantly overestimates PAN in the UT by $20-60$ pptv in DJF between 200 and $100 \mathrm{hPa}$. In JJA and SON, significant positive biases (20-40 pptv) occur near the NH tropopause. In the LS, TOMCAT significantly underestimates MIPAS by $0-30$ pptv in most seasons. 

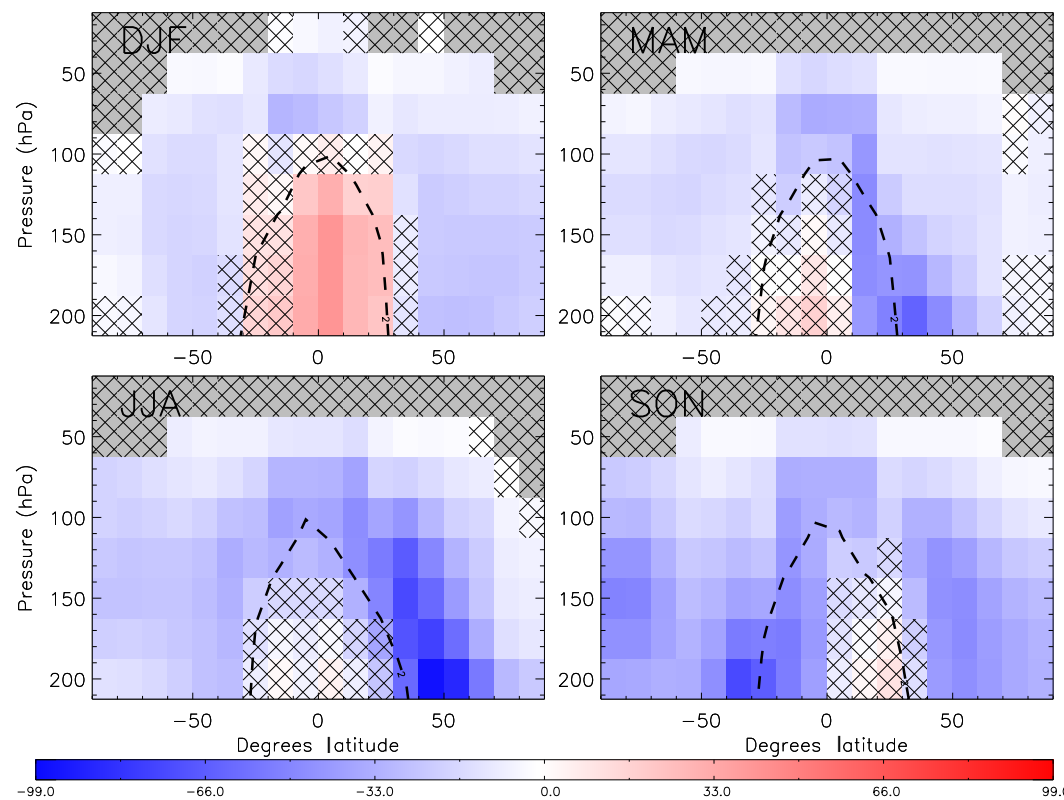

Figure 16. Difference in zonal mean PAN (pptv) between the TOMCAT model (with IMK AKs applied) and observed IMK MIPAS PAN for 2007-2008 in DJF, MAM, JJA, and SON. Hatching represents non-significant differences.
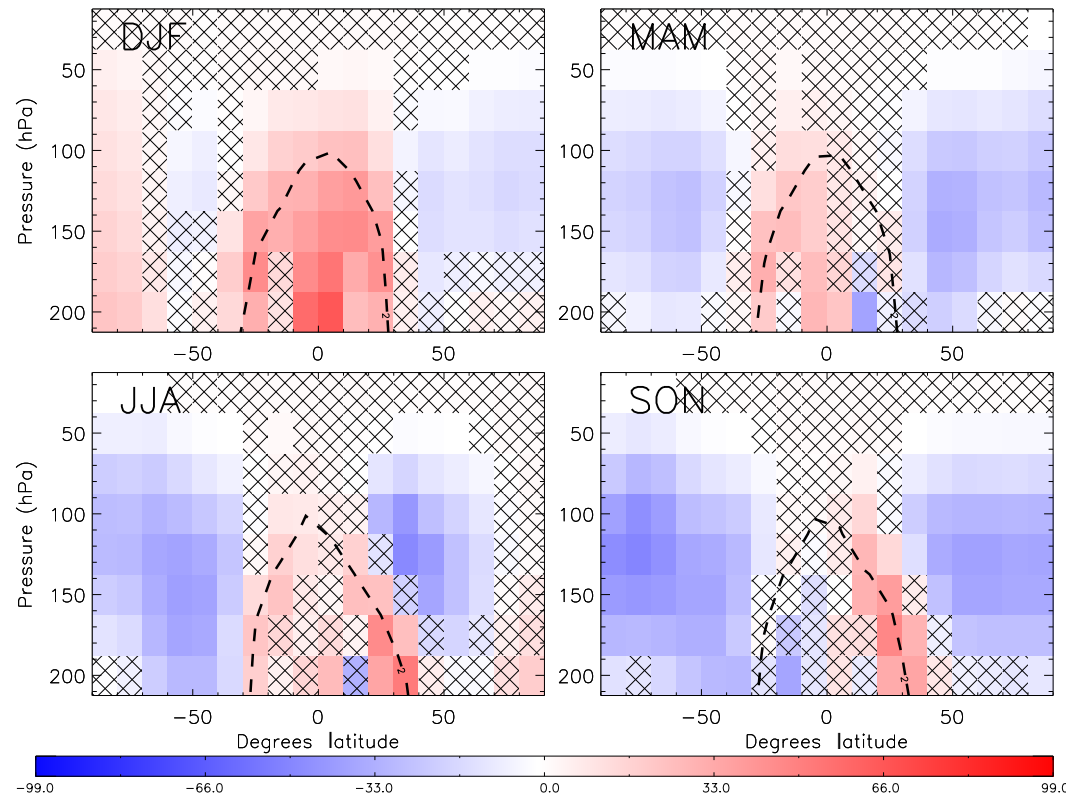

Figure 17. As Fig. 16 but for UoL MIPAS observations and application of the UoL averaging kernels to the TOMCAT model output.

Overall, TOMCAT significantly underestimates IMK and UoL MIPAS PAN in the LS in all seasons (except for UoL MIPAS PAN in DJF). In the UT, TOMCAT tends to significantly underestimate IMK MIPAS PAN, especially in the biomass burning regions. In DJF, the TOMCAT PAN concentrations are large compared with both MIPAS PAN products over tropical South America and South-east Asia. When compared with UoL MIPAS PAN in the UT, TOMCAT overestimates by 10-90 pptv. Typically, there is some consistency between the two MIPAS products in the LS. However, in the UT, the IMK MIPAS PAN concentrations are larger than the UoL with TOMCAT values in between them. Fadnavis et al. (2014) found that ECHAM5-HAMMOZ simulations underestimated IMK MIPAS PAN concentrations in the summertime Asian monsoon. Emmons et al. (2015) and Arnold et al. (2015) found that TOMCAT overestimates aircraft-observed PAN in the troposphere. Emmons et al. (2015) found biases between -10 and $+30 \%$ between 3 and $7 \mathrm{~km}$, with a 
large bias occurring against some springtime flights $(+80 \%)$. As shown here, the largest TOMCAT biases are in spring (Fig. 8), but differences are generally within the variability of the aircraft observations. Even though these comparisons are not at altitudes observed by satellite, it quantifies the skill of TOMCAT and allows us to use the model as a tool to better understand UTLS PAN. This gives us confidence to state that there are inconsistencies between the two MIPAS PAN datasets as IMK and UoL MIPAS PAN are positively and negatively biased with the model in the UT.

\section{Conclusions}

We have compared two independent MIPAS retrievals of PAN which are produced by IMK, Karlsruhe, and the University of Leicester. We analysed observations for the 2year period 2007-2008 in the upper troposphere and lower stratosphere. Overall, the IMK MIPAS PAN has significantly larger concentrations in the upper troposphere over the tropics by $50-100$ pptv, when compared with UoL data. In the lower stratosphere, the UoL concentrations are larger by 0 30 pptv; however, these differences are only significant in the northern high latitudes in MAM and JJA. Both retrieved datasets show peak PAN concentrations over the African biomass burning regions ( $>200 \mathrm{pptv}$ ), but the IMK data has a clearer summertime Asian monsoon signal. Here, enhanced convection leads to increased vertical transport of PAN into the UTLS and the outflow ranges from 150 to $>200$ pptv. When compared with PAN from ACE-FTS, the MIPAS profile uncertainties generally overlap with those from the ACEFTS in the UTLS. At $200-175 \mathrm{hPa}$, IMK MIPAS PAN tends to overestimate the other two products. Between 75 and $25 \mathrm{hPa}$, the ACE-FTS PAN concentrations tend to be larger than the MIPAS profiles (though in agreement with IMK MIPAS PAN at $30-60^{\circ} \mathrm{N}$ and $\mathrm{S}$ ).

The TOMCAT global CTM was used to help quantify the global distribution of PAN. At $150 \mathrm{hPa}$, TOMCAT significantly underestimates upper-tropospheric IMK MIPAS PAN by 50 to $>100$ pptv in the biomass burning regions in MAM and SON. It also underestimates the observed lower stratospheric PAN in all seasons. When compared with UoL MIPAS PAN, TOMCAT significantly overestimates the observations by $10-70 \mathrm{pptv}$ in the upper troposphere (tropics) and underestimates them by $10-40 \mathrm{pptv}$ in the lower stratosphere (mid-high latitudes). Previous publications (e.g. Emmons et al., 2015) have shown that TOMCAT overestimates PAN in the troposphere and the comparisons between TOMCAT and aircraft data in this study show similar patterns in the spring ARCTAS campaign, when lower-tropospheric PAN is particularly stable and long-lived, and at several regions in the Emmons et al. (2000) aircraft climatology. However, the model does a good job at capturing PAN during summer. In the UTLS, TOMCAT PAN reproduces the observations, given the large uncertainty in aircraft measurements.
Based on the inter-comparison of satellite products and comparison of TOMCAT with observations, we suggest that there are inconsistencies between the two MIPAS PAN datasets as IMK and UoL MIPAS PAN are positively and negatively biased with the model in the upper troposphere.

\section{Data availability}

Chemical tracers from the TOMCAT chemical transport model are available from the University of Leeds for the purpose of academic collaborations and scientific research. For access to the data, please contact Richard Pope (r.j.pope @leeds.ac.uk) or Martyn Chipperfield (m.chipperfield@leeds.ac.uk). Chemical tracers retrieved by MIPAS are provided by the Karlsruhe Institute of Technology and can be found at https://www.imk-asf.kit.edu/ english/308.php. PAN retrieved by MIPAS and ACE-FTS is available on request from the University of Leicester for the purpose of academic collaborations and scientific research. For access to the MIPAS and ACE-FTS data, please contact David Moore (david.moore@le.ac.uk) and Jeremy Harrison (jh592@leicester.ac.uk), respectively. The ARCTAS and ARCPAC aircraft data are available from http://www-air.larc.nasa.gov/missions/arctas/arctas.html and http://www.esrl.noaa.gov/csd/projects/arcpac/, respectively. The multi-year regional aircraft composite dataset compiled by Emmons et al. (2000) is available at https://www2.acom. ucar.edu/gcm/aircraft-climatology.

\section{The Supplement related to this article is available online at doi:10.5194/acp-16-13541-2016-supplement.}

Acknowledgements. This work was supported by the NERC National Centre for Earth Observation (NCEO). We are grateful to Paul Young (University of Lancaster) for supplying the TOMCAT isoprene scheme. We acknowledge the use of Emmons et al. (2000) aircraft climatology of atmospheric trace gases, which is available at https://www2.acom.ucar.edu/gcm/aircraft-climatology. We also thank the NOAA Earth System Research Laboratory Chemical Sciences Division for the ARCPAC CO aircraft data. The ACE mission is funded primarily by the Canadian Space Agency (http://www.asc-csa.gc.ca/eng/). PTR-MS measurements during ARCTAS were funded through the Austrian Space Applications Programme (ASAP). ASAP is sponsored by the Austrian Ministry for Transport and administered by the Aeronautics and Space Agency (ALR) of the Austrian Research Promotion Agency (FFG). Tomas Mikoviny is acknowledged for his support in the PTR-MS data acquisition and analysis.

Edited by: R. Müller

Reviewed by: two anonymous referees 


\section{References}

Arnold, S. R., Emmons, L. K., Monks, S. A., Law, K. S., Ridley, D. A., Turquety, S., Tilmes, S., Thomas, J. L., Bouarar, I., Flemming, J., Huijnen, V., Mao, J., Duncan, B. N., Steenrod, S., Yoshida, Y., Langner, J., and Long, Y.: Biomass burning influence on high-latitude tropospheric ozone and reactive nitrogen in summer 2008: a multi-model analysis based on POLMIP simulations, Atmos. Chem. Phys., 15, 6047-6068, doi:10.5194/acp15-6047-2015, 2015. .

Belmonte Rivas, M., Veefkind, P., Eskes, H., and Levelt, P.: OMI tropospheric $\mathrm{NO}_{2}$ profiles from cloud slicing: constraints on surface emissions, convective transport and lightning $\mathrm{NO}_{x}$, Atmos. Chem. Phys., 15, 13519-13553, doi:10.5194/acp-1513519-2015, 2015.

Bernath, P. F., McElroy, C. T., Abrams, M. C., Boone, C. D., Butler, M., Camy-Peyret, C., Carleer, M., Clerbaux, C., Coheur, P.-F., Colin, R., DeCola, P., DeMazière, M., Drummond, J. R., Dufour, D., Evans, W. F. J., Fast, H., Fussen, D., Gilbert, K., Jennings, D. E., Llewellyn, E. J., Lowe, R. P., Mahieu, E., McConnell, J. C., McHugh, M., McLeod, S. D., Michaud, R., Midwinter, C., Nassar, R., Nichitiu, F., Nowlan, C., Rinsland, C. P., Rochon, Y. J., Rowlands, N., Semeniuk, K., Simon, P., Skelton, R., Sloan, J. J., Soucy, M.-A., Strong, K., Tremblay, P., Turnbull, D., Walker, K. A., Walkty, I., Wardle, D. A., Wehrle, V., Zander, R., and Zou, J.: Atmospheric Chemistry Experiment (ACE): Mission overview, Geophys. Res. Lett., 32, 115S01, doi:10.1029/2005GL022386, 2005.

Brock, C. A., Cozic, J., Bahreini, R., Froyd, K. D., Middlebrook, A. M., McComiskey, A., Brioude, J., Cooper, O. R., Stohl, A., Aikin, K. C., de Gouw, J. A., Fahey, D. W., Ferrare, R. A., Gao, R.-S., Gore, W., Holloway, J. S., Hübler, G., Jefferson, A., Lack, D. A., Lance, S., Moore, R. H., Murphy, D. M., Nenes, A., Novelli, P. C., Nowak, J. B., Ogren, J. A., Peischl, J., Pierce, R. B., Pilewskie, P., Quinn, P. K., Ryerson, T. B., Schmidt, K. S., Schwarz, J. P., Sodemann, H., Spackman, J. R., Stark, H., Thomson, D. S., Thornberry, T., Veres, P., Watts, L. A., Warneke, C., and Wollny, A. G.: Characteristics, sources, and transport of aerosols measured in spring 2008 during the aerosol, radiation, and cloud processes affecting Arctic Climate (ARCPAC) Project, Atmos. Chem. Phys., 11, 2423-2453, doi:10.5194/acp-11-24232011, 2011.

Chipperfield, M. P.: New version of the TOMCAT/SLIMCAT offline chemical transport model: Intercomparison of stratospheric tracer experiments, Q. J. Roy. Meteor. Soc., 132, 1179-1203, doi:10.1256/qj.05.51, 2006

Chipperfield, M. P., Cariolle, D., Simon, P., Ramaroson, R., and Lary, D. J.: A three-dimensional modeling study of trace species in the Arctic lower stratosphere during winter 1989-1990, J. Geophys. Res.-Atmos., 98, 7199-7218, doi:10.1029/92JD02977, 1993.

Emmons, L. K., Hauglustaine, D. A., Muller, J., Carroll, M. A., Brasseur, G. P., Brunner, D., Staehelin, J., Thouret, V., and Marenco, A.: Data composites of airborne observations of tropospheric ozone and its precursors, J. Geophys. Res.-Atmos., 105, 20497-20538, doi:10.1029/2000JD900232, 2000.

Emmons, L. K., Arnold, S. R., Monks, S. A., Huijnen, V., Tilmes, S., Law, K. S., Thomas, J. L., Raut, J.-C., Bouarar, I., Turquety, S., Long, Y., Duncan, B., Steenrod, S., Strode, S., Flemming, J., Mao, J., Langner, J., Thompson, A. M., Tarasick, D., Apel, E.
C., Blake, D. R., Cohen, R. C., Dibb, J., Diskin, G. S., Fried, A., Hall, S. R., Huey, L. G., Weinheimer, A. J., Wisthaler, A., Mikoviny, T., Nowak, J., Peischl, J., Roberts, J. M., Ryerson, T., Warneke, C., and Helmig, D.: The POLARCAT Model Intercomparison Project (POLMIP): overview and evaluation with observations, Atmos. Chem. Phys., 15, 6721-6744, doi:10.5194/acp15-6721-2015, 2015.

Evans, M. J. and Jacob, D. J.: Impact of new laboratory studies of $\mathrm{N}_{2} \mathrm{O}_{5}$ hydrolysis on global model budgets of tropospheric nitrogen oxides, ozone, and OH, Geophys. Res. Lett., 32, 109813, doi:10.1029/2005GL022469, 2005.

Fadnavis, S., Schultz, M. G., Semeniuk, K., Mahajan, A. S., Pozzoli, L., Sonbawne, S., Ghude, S. D., Kiefer, M., and Eckert, E.: Trends in peroxyacetyl nitrate (PAN) in the upper troposphere and lower stratosphere over southern Asia during the summer monsoon season: regional impacts, Atmos. Chem. Phys., 14, 12725-12743, doi:10.5194/acp-14-12725-2014, 2014.

Fischer, E. V., Jacob, D. J., Yantosca, R. M., Sulprizio, M. P., Millet, D. B., Mao, J., Paulot, F., Singh, H. B., Roiger, A., Ries, L., Talbot, R. W., Dzepina, K., and Pandey Deolal, S.: Atmospheric peroxyacetyl nitrate (PAN): a global budget and source attribution, Atmos. Chem. Phys., 14, 2679-2698, doi:10.5194/acp-142679-2014, 2014.

Fischer, H., Birk, M., Blom, C., Carli, B., Carlotti, M., von Clarmann, T., Delbouille, L., Dudhia, A., Ehhalt, D., Endemann, M., Flaud, J. M., Gessner, R., Kleinert, A., Koopman, R., Langen, J., López-Puertas, M., Mosner, P., Nett, H., Oelhaf, H., Perron, G., Remedios, J., Ridolfi, M., Stiller, G., and Zander, R.: MIPAS: an instrument for atmospheric and climate research, Atmos. Chem. Phys., 8, 2151-2188, doi:10.5194/acp-8-2151-2008, 2008.

Glatthor, N., Hoepfner, M., Stiller, G. P., von Clarmann, T., Dudhia, A., Echle, G., Funke, B., and Hase, F.: Intercomparison of the KOPRA and the RFM radiative transfer codes, Proc. SPIE, 3867, 348-363, doi:10.1117/12.373077, 1999.

Glatthor, N., von Clarmann, T., Fischer, H., Funke, B., Grabowski, U., Höpfner, M., Kellmann, S., Kiefer, M., Linden, A., Milz, M., Steck, T., and Stiller, G. P.: Global peroxyacetyl nitrate (PAN) retrieval in the upper troposphere from limb emission spectra of the Michelson Interferometer for Passive Atmospheric Sounding (MIPAS), Atmos. Chem. Phys., 7, 2775-2787, doi:10.5194/acp7-2775-2007, 2007.

Granier, C., Bessagnet, B., Bond, T., D’Angiola, A., Denier van der Gon, H., Frost, G. J., Heil, A., Kaiser, J. W., Kinne, S., Klimont, Z., Kloster, S., Lamarque, J.-F., Liousse, C., Masui, T., Meleux, F., Mieville, A., Ohara, T., Raut, J.-C., Riahi, K., Schultz, M. G., Smith, S. J., Thompson, A., Aardenne, J., Werf, G. R., and Vuuren, D. P.: Evolution of anthropogenic and biomass burning emissions of air pollutants at global and regional scales during the 1980-2010 period, Climatic Change, 109, 163-190, doi:10.1007/s10584-011-0154-1, 2011.

Holtslag, A. A. M. and Boville, B. A.: Local Versus Nonlocal Boundary-Layer Diffusion in a Global Climate Model, J. Climate, 6, 1825-1842, 1993

Hudman, R. C., Jacob, D. J., Cooper, O. R., Evans, M. J., Heald, C. L., Park, R. J., Fehsenfeld, F., Flocke, F., Holloway, J., Hübler, G., Kita, K., Koike, M., Kondo, Y., Neuman, A., Nowak, J., Oltmans, S., Parrish, D., Roberts, J. M., and Ryerson, T.: Ozone production in transpacific Asian pollution plumes and implications 
for ozone air quality in California, J. Geophys. Res.-Atmos., 109, d23S10, doi:10.1029/2004JD004974, 2004.

Ito, A., Sillman, S., and Penner, J. E.: Effects of additional nonmethane volatile organic compounds, organic nitrates, and direct emissions of oxygenated organic species on global tropospheric chemistry, J. Geophys. Res.-Atmos., 112, d06309, doi:10.1029/2005JD006556,2007.

Jacob, D. J., Crawford, J. H., Maring, H., Clarke, A. D., Dibb, J. E., Emmons, L. K., Ferrare, R. A., Hostetler, C. A., Russell, P. B., Singh, H. B., Thompson, A. M., Shaw, G. E., McCauley, E., Pederson, J. R., and Fisher, J. A.: The Arctic Research of the Composition of the Troposphere from Aircraft and Satellites (ARCTAS) mission: design, execution, and first results, Atmos. Chem. Phys., 10, 5191-5212, doi:10.5194/acp-10-5191-2010, 2010.

Lewis, A. C., Evans, M. J., Methven, J., Watson, N., Lee, J. D., Hopkins, J. R., Purvis, R. M., Arnold, S. R., McQuaid, J. B., Whalley, L. K., Pilling, M. J., Heard, D. E., Monks, P. S., Parker, A. E., Reeves, C. E., Oram, D. E., Mills, G., Bandy, B. J., Stewart, D., Coe, H., Williams, P., and Crosier, J.: Chemical composition observed over the mid-Atlantic and the detection of pollution signatures far from source regions, J. Geophys. Res.-Atmos., 112, d10S39, doi:10.1029/2006JD007584, 2007.

Li, Q., Palmer, P. I., Pumphrey, H. C., Bernath, P., and Mahieu, E.: What drives the observed variability of $\mathrm{HCN}$ in the troposphere and lower stratosphere?, Atmos. Chem. Phys., 9, 85318543, doi:10.5194/acp-9-8531-2009, 2009.

Mann, G. W., Carslaw, K. S., Spracklen, D. V., Ridley, D. A., Manktelow, P. T., Chipperfield, M. P., Pickering, S. J., and Johnson, C. E.: Description and evaluation of GLOMAP-mode: a modal global aerosol microphysics model for the UKCA composition-climate model, Geosci. Model Dev., 3, 519-551, doi:10.5194/gmd-3-519-2010, 2010.

Mogili, P. K., Kleiber, P. D., Young, M. A., and Grassian, V. H.: $\mathrm{N}_{2} \mathrm{O}_{5}$ hydrolysis on the components of mineral dust and sea salt aerosol: Comparison study in an environmental aerosol reaction chamber, Atmos. Environ., 40, 7401-7408, doi:10.1016/j.atmosenv.2006.06.048, 2006.

Monks, S. A.: A model study of chemistry and transport in the Arctic troposphere, PhD Thesis, School of Earth and Environment, University of Leeds, 230 pp., 2011.

Monks, S. A., Arnold, S. R., Emmons, L. K., Law, K. S., Turquety, S., Duncan, B. N., Flemming, J., Huijnen, V., Tilmes, S., Langner, J., Mao, J., Long, Y., Thomas, J. L., Steenrod, S. D., Raut, J. C., Wilson, C., Chipperfield, M. P., Diskin, G. S., Weinheimer, A., Schlager, H., and Ancellet, G.: Multi-model study of chemical and physical controls on transport of anthropogenic and biomass burning pollution to the Arctic, Atmos. Chem. Phys., 15, 3575-3603, doi:10.5194/acp-15-3575-2015, 2015.

Moore, D. P. and Remedios, J. J.: Seasonality of Peroxyacetyl nitrate (PAN) in the upper troposphere and lower stratosphere using the MIPAS-E instrument, Atmos. Chem. Phys., 10, 6117-6128, doi:10.5194/acp-10-6117-2010, 2010.

Pfister, G. G., Emmons, L. K., Hess, P. G., Lamarque, J.-F., Orlando, J. J., Walters, S., Guenther, A., Palmer, P. I., and Lawrence, P. J.: Contribution of isoprene to chemical budgets: A model tracer study with the NCAR CTM MOZART-4, J. Geophys. Res.-Atmos., 113, d05308, doi:10.1029/2007JD008948, 2008.

Pöschl, U., von Kuhlmann, R., Poisson, N., and Crutzen, P.: Development and Intercomparison of Condensed Isoprene Oxida- tion Mechanisms for Global Atmospheric Modeling, J. Atmos. Chem., 37, 29-52, doi:10.1023/A:1006391009798, 2000.

Prather, M. J.: Numerical advection by conservation of secondorder moments, J. Geophys. Res.-Atmos., 91, 6671-6681, doi:10.1029/JD091iD06p06671, 1986.

Randerson, J. T., van der Werf, G. R., Giglio, L., Collatz, G. J., and Kasibhatla, P. S.: Global Fire Emissions Database, Version 3 (GFEDv3.1), Dataset, available at: http://daac.ornl.gov/ from Oak Ridge National Laboratory Distributed Active Archive Center, Oak Ridge, Tennessee, USA, available at: https://daac.ornl. gov/cgi-bin/dsviewer.pl?ds_id=1191 (last access: March 2015), 2013.

Richards, N. A. D., Arnold, S. R., Chipperfield, M. P., Miles, G., Rap, A., Siddans, R., Monks, S. A., and Hollaway, M. J.: The Mediterranean summertime ozone maximum: global emission sensitivities and radiative impacts, Atmos. Chem. Phys., 13, 2331-2345, doi:10.5194/acp-13-2331-2013, 2013.

Roberts, J. M., Flocke, F., Chen, G., de Gouw, J., Holloway, J. S., Hübler, G., Neuman, J. A., Nicks, D. K., Nowak, J. B., Parrish, D. D., Ryerson, T. B., Sueper, D. T., Warneke, C., and Fehsenfeld, F. C.: Measurement of peroxycarboxylic nitric anhydrides (PANs) during the ITCT 2K2 aircraft intensive experiment, J. Geophys. Res.-Atmos., 109, d23S21, doi:10.1029/2004JD004960, 2004.

Russo, R. S., Talbot, R. W., Dibb, J. E., Scheuer, E., Seid, G., Jordan, C. E., Fuelberg, H. E., Sachse, G. W., Avery, M. A., Vay, S. A., Blake, D. R., Blake, N. J., Atlas, E., Fried, A., Sandholm, S. T., Tan, D., Singh, H. B., Snow, J., and Heikes, B. G.: Chemical composition of Asian continental outflow over the western Pacific: Results from Transport and Chemical Evolution over the Pacific (TRACE-P), J. Geophys. Res.-Atmos., 108, 8804, doi:10.1029/2002JD003184, 2003.

Singh, H., Viezee, W., Chen, Y., Bradshaw, J., Sandholm, S., Blake, D., Blake, N., Heikes, B., Snow, J., Talbot, R., Browell, E., Gregory, G., Sachse, G., and Vay, S.: Biomass burning influences on the composition of the remote South Pacific troposphere: analysis based on observations from PEM-Tropics-A, Atmos. Environ., 34, 635-644, doi:10.1016/S1352-2310(99)00380-5, 2000.

Singh, H. B.: Reactive nitrogen in the troposphere, Environ. Sci. Technol., 21, 320-327, doi:10.1021/es00158a001, 1987.

Singh, H. B., Herlth, D., Kolyer, R., Chatfield, R., Viezee, W., Salas, L. J., Chen, Y., Bradshaw, J. D., Sandholm, S. T., Talbot, R., Gregory, G. L., Anderson, B., Sachse, G. W., Browell, E., Bachmeier, A. S., Blake, D. R., Heikes, B., Jacob, D., and Fuelberg, H. E.: Impact of biomass burning emissions on the composition of the South Atlantic troposphere: Reactive nitrogen and ozone, J. Geophys. Res.-Atmos., 101, 24203-24219, doi:10.1029/96JD01018, 1996.

Stockwell, D. Z. and Chipperfield, M. P.: A tropospheric chemicaltransport model: Development and validation of the model transport schemes, Q. J. Roy. Meteor. Soc., 125, 1747-1783, doi:10.1002/qj.49712555714, 1999.

Talukdar, R. K., Burkholder, J. B., Schmoltner, A.-M., Roberts, J. M., Wilson, R. R., and Ravishankara, A. R.: Investigation of the loss processes for peroxyacetyl nitrate in the atmosphere: UV photolysis and reaction with $\mathrm{OH}$, J. Geophys. Res.-Atmos., 100, 14163-14173, doi:10.1029/95JD00545, 1995.

Tereszchuk, K. A., Moore, D. P., Harrison, J. J., Boone, C. D., Park, M., Remedios, J. J., Randel, W. J., and Bernath, P. F.: Obser- 
vations of peroxyacetyl nitrate (PAN) in the upper troposphere by the Atmospheric Chemistry Experiment-Fourier Transform Spectrometer (ACE-FTS), Atmos. Chem. Phys., 13, 5601-5613, doi:10.5194/acp-13-5601-2013, 2013.

Tiedtke, M.: A comprehensive mass flux scheme for cumulus parameterization in large-scale models, Mon. Weather Rev., 117, 1779-1800, 1989.

Ungermann, J., Ern, M., Kaufmann, M., Müller, R., Spang, R., Ploeger, F., Vogel, B., and Riese, M.: Observations of PAN and its confinement in the Asian summer monsoon anticyclone in high spatial resolution, Atmos. Chem. Phys., 16, 8389-8403, doi:10.5194/acp-16-8389-2016, 2016

Wang, K.-Y., Pyle, J. A., Sanderson, M. G., and Bridgeman, C.: Implementation of a convective atmospheric boundary layer scheme in a tropospheric chemistry transport model, J. Geophys. Res.Atmos., 104, 23729-23745, doi:10.1029/1999JD900383, 1999.

Wang, Y., Logan, J. A., and Jacob, D. J.: Global simulation of tropospheric $\mathrm{O}_{3}-\mathrm{NO}_{x}$-hydrocarbon chemistry: 2. Model evaluation and global ozone budget, J. Geophys. Res.: Atmos., 103, 1072710755, doi:10.1029/98JD00157, 1998.
Warneke, C., Froyd, K. D., Brioude, J., Bahreini, R., Brock, C. A., Cozic, J., de Gouw, J. A., Fahey, D. W., Ferrare, R., Holloway, J. S., Middlebrook, A. M., Miller, L., Montzka, S., Schwarz, J. P., Sodemann, H., Spackman, J. R., and Stohl, A.: An important contribution to springtime Arctic aerosol from biomass burning in Russia, Geophys. Res. Lett., 37, 101801, doi:10.1029/2009GL041816, 2010.

Wiegele, A., Glatthor, N., Höpfner, M., Grabowski, U., Kellmann, S., Linden, A., Stiller, G., and von Clarmann, T.: Global distributions of $\mathrm{C}_{2} \mathrm{H}_{6}, \mathrm{C}_{2} \mathrm{H}_{2}, \mathrm{HCN}$, and PAN retrieved from MIPAS reduced spectral resolution measurements, Atmos. Meas. Tech., 5, 723-734, doi:10.5194/amt-5-723-2012, 2012. 